\section{OPEN ACCESS}

Edited by:

Masoud Mozafari,

University of Toronto, Canada

Reviewed by:

Francesco Baino,

Politecnico di Torino, Italy

Saulius Juodkazis,

Swinburne University of Technology,

Australia

Zohaib Khurshid,

King Faisal University, Saudi Arabia

Silvia Spriano,

Politecnico di Torino, Italy

*Correspondence:

Shokouh Attarilar

sh.attarilar@yahoo.com

Specialty section:

This article was submitted to

Biomaterials,

a section of the journal

Frontiers in Materials

Received: 26 December 2020

Accepted: 16 April 2021

Published: 13 May 2021

Citation:

Kandavalli $S R$, Wang $Q$

Ebrahimi M, Gode C, Djavanroodi F

Attarilar S and Liu S (2021) A Brief

Review on the Evolution of Metallic

Dental Implants: History, Design,

and Application.

Front. Mater. 8:646383.

doi: 10.3389/fmats.2021.646383

\title{
A Brief Review on the Evolution of Metallic Dental Implants: History, Design, and Application
}

\section{Sumanth Ratna Kandavalli', Qingge Wang ${ }^{2}$, Mahmoud Ebrahimi ${ }^{3}$, Ceren Gode4, Faramarz Djavanroodi5,6, Shokouh Attarilar ${ }^{7 *}$ and Shifeng Liu ${ }^{2}$}

${ }^{1}$ Department of Mechanical Engineering, Karunya Institute of Technology \& Sciences, Coimbatore, India, ${ }^{2}$ School of Metallurgical Engineering, Xi'an University of Architecture and Technology, Xi'an, China, ${ }^{3}$ National Engineering Research Center of Light Alloy Net Forming, School of Materials Science and Engineering, Shanghai Jiao Tong University, Shanghai, China, ${ }^{4}$ Program of Machine, School of Denizli Vocational Technology, Pamukkale University, Denizli, Turkey, ${ }^{5}$ Department of Mechanical Engineering, College of Engineering, Prince Mohammad Bin Fahd University, Al Khobar, Saudi Arabia, ${ }^{6}$ Department of Mechanical Engineering, Imperial College London, London, United Kingdom, ${ }^{7}$ State Key Laboratory of Metal Matrix Composites, School of Material Science and Engineering, Shanghai Jiao Tong University, Shanghai, China

In recent years, significant advances in the field of medical materials have begun to emerge, especially in nanotechnology. The modern area of nanostructured implants possesses wide applications in various medical implants including their dental use. Nano-surface functions present substantial resolutions to medical obstacles through improved biomaterial proficiency, innovative dental-implant designs, and surface design procedures, such as nanoscale adhesive surfaces, bio-chemical anodization, and surface modification technique. This work covers dental implant history, nanotechnological advances, and its development that includes a description, basic properties, and the related results of composites and surface morphology, and the different types of nanomaterials used in dental implants. Significant attempts have been made over the last few decades to strengthen osteointegration and prevent bacterial attachment to the implant surfaces. The micro and nano-topography of the hierarchical surface orchestrate the biological reactions of implants and may solve the problems associated with implant-tissue issues. This research investigates the implant articles from 1964 to 2021, which offers a brief description of the nanostructured biomaterials to enhance dental implants' performance and may open new frontiers in the advancement of implant technology.

Keywords: dental implant, nanomodified implants, nanoscale modification, antibacterial, osseointegration, surface treatment

\section{INTRODUCTION}

In recent years, the utilization of dental implants has been widely increased for enhancing the human lives' standard. In the United States alone, in 2006, about 5.5 million implants were cultured, in 2018, the sum of US dental implants was about five trillion dollars (Alani et al., 2014). The production of various biocompatible components, materials, and technical frameworks might come to extend the spectrum of bio-based uses in relation to dentistry implants (Bhat and Kumar, 2013), 
still there remain some issues. One of the main challenges is the first step of implantation in which various problems may arise like infections, poor osteointegration, and other side effects. There are many types of problems in dentistry such as root canal issues, infectious gums, biofilm formation (Dohan Ehrenfest et al., 2010; Gupta et al., 2010). The process for implantation and examples of dental implants is shown in Figure 1. As can be observed, after drilling the hole, the dental implants are inserted into the bone with a special torquing instrument, and then the dental prosthesis is embedded (Nelson et al., 2013). New engineering techniques could improve mechanical properties, biocompatibility, and biomedical efficiency (Ansarian et al., 2019a,b; Andrade et al., 2020). Various biomaterials have been used for the restoration and healing of damaged and stressed organs (Stojkovic et al., 2014), especially for the reconstruction of tissue (Jin et al., 2003). In this regard, nanotechnology is one of the most rapidly evolving areas of biomaterials tissue science (Kaminski et al., 2012; Jastrzebska et al., 2014). Also, CAD/CAMbased technologies are slowly spread across the entire medical sector (Van Noort, 2012; Zhao et al., 2012; Zandparsa, 2014; Yang and Miyanaji, 2017). In addition, dentistry is increasingly using additive manufacturing (AM) techniques. AM methods are based on $3 \mathrm{D}$ model data and they produce samples through layer by layer technique (Davis, 2010; International ASTM, 2014).

Dental implants are usually employed as substitutes for missing teeth, the main causes of tooth decay are inflamed gums, poor root canal, infections, etc. Changing missing teeth with a longstanding dental implant is a sophisticated alternative, one of the most promising treatments for broken teeth is the application of dental implants. Dental implants can be made of various types of materials, such as ceramics, shells, cobalt-chromium, gold, copper, titanium, and Iridio-Platinum (Crabb, 2006). In ancient China, people have used Bamboo stick pins around 4000 years ago (Misch, 1999). Ancient Egyptian slaves gave Pharaohs their teeth (Cohen et al., 1995). Hetero-plastics are often used for animal tooth substitution and homo-plastics for human teeth (Smeets et al., 2016). In 1952, the first popular modern dental implants were made with titanium (Ti) basins encapsulated in the rabbit bone. In 1971, Brånemark dental replacements were used (Branemark, 1983). Research findings in modern dental evolution show that $\mathrm{Ti}$ is the most popular material. The osseointegration is one of the major problems in the background of dental implants, it was identified that bone can adhere and grow on substrates like $\mathrm{Ti}$, but its growth may be impeded during a certain process (Brånemark et al., 1964). Ceramics or ceramicglasses can be utilized in the surface treatment of implants in order to improve osseointegration (Webster et al., 1999). In addition, these ceramics or ceramic-glasses are highly translucent due to the optical compatibility between the glassy matrix and the crystalline phase, which minimizes the internal scattering of the light. Moreover, surface structure plays a vital role in dental implants. Table 1 lists the evolution of dental implants from past up to recent dates. Moreover, surface structure plays a vital role in dental implants. Nanoparticles (NPs) have lots of applications in the dental industry as listed in Table 2. Metallic dental implants are used for a long time; however, lack of osseointegration effect, ease of infection, and unmatched mechanical properties are major drawbacks (Linkow, 1966; Schroeder et al., 1981; Derrick, 1986; Zwemer, 1986; Greenfield, 1991; Linkow and Dorfman, 1991; Burch, 1997; Pjetursson et al., 2007; Yong and Moy, 2008; Lavenus et al., 2012; Abraham, 2014; Soto-Peñaloza et al., 2017; Attarilar et al., 2019, 2020; Gonçalves et al., 2019).

The implant quality can be assessed by three specific aspects like physio-chemical, topographical, and mechanical characteristics, these features are relatively interconnected and any improvement in these features may affect others (Pachauri et al., 2014). The reaction of the implant is directly related to its periphery tissue and its integration with this surrounding zone. Establishing a nanostructured surface implant can promote osseointegration (Wang et al., 2020b). The creation of a nanoscale surface structure is a suitable choice.

\section{NANOTECHNOLOGY IN DENTAL IMPLANTS}

Nanotechnology includes the development and use of nanoscale materials in terms of size and structure-dependent properties (Wang et al., 2020a,b). A nano-material is defined as 1 to $100 \mathrm{~nm}$ sized particles (Uludag et al., 2001; Roco, 2004; Kumar and Vijayalakshmi, 2006; Zhang and Uludağ, 2009; Akbarian et al., 2017; Barhoum et al., 2017; ElMaghrabi et al., 2018; Jeevanandam et al., 2018). One of the prime aims of nanotechnology in the dental implant field is to increase osseointegration behavior (Coelho et al., 2009). Surface modification techniques (such as acid etching, alkali surface treatment, sol-gel, and chemical vapor deposition) offer opportunities to implement better dental implants, especially in the micro and nanoscales through design and interfacial engineering (Catledge et al., 2002; Karazisis et al., 2016; Chen et al., 2018). As shown in Figure 2, there are several examples of different types of topographies used to mimic the extracellular matrix of tissues.

Some beneficial examples of nanosized topographies are as follows, gradual degradation of nanosized thin CaP-coatings in implants enhances the ionic force and accumulation of the blood and biological precipitation of apatite crystal on the surface of the implant. The anti-inflammatory $\mathrm{TiO}_{2}$ nanotubes provide a steady discharge of the drugs during the implant procedure, maintain effective treatment efficacy on-site, and reduce the negative side effects during the oral medication process (Leeuwenburgh et al., 2001; Shokuhfar et al., 2013; Jang et al., 2018). Also, the density and dimensions of the nanostructures influence cell function (Zhao et al., 2006), cell adhesion is another important aspect of the nanoscale structure. A study reported nanostructure surface increased osteoblast compared with a smooth surface. The adherence of osteoblasts depended on the surface morphology rather than chemical composition, grain and pore size. However, chemical composition, grain and pore size are the main parameters affecting cell response. In addition, the surface characteristics of the implant can influence the development of the bone, along with weight resistance and adaptability (Streicher et al., 2007). Gittens et al. (2011) developed a simple surface modification technology, which could 


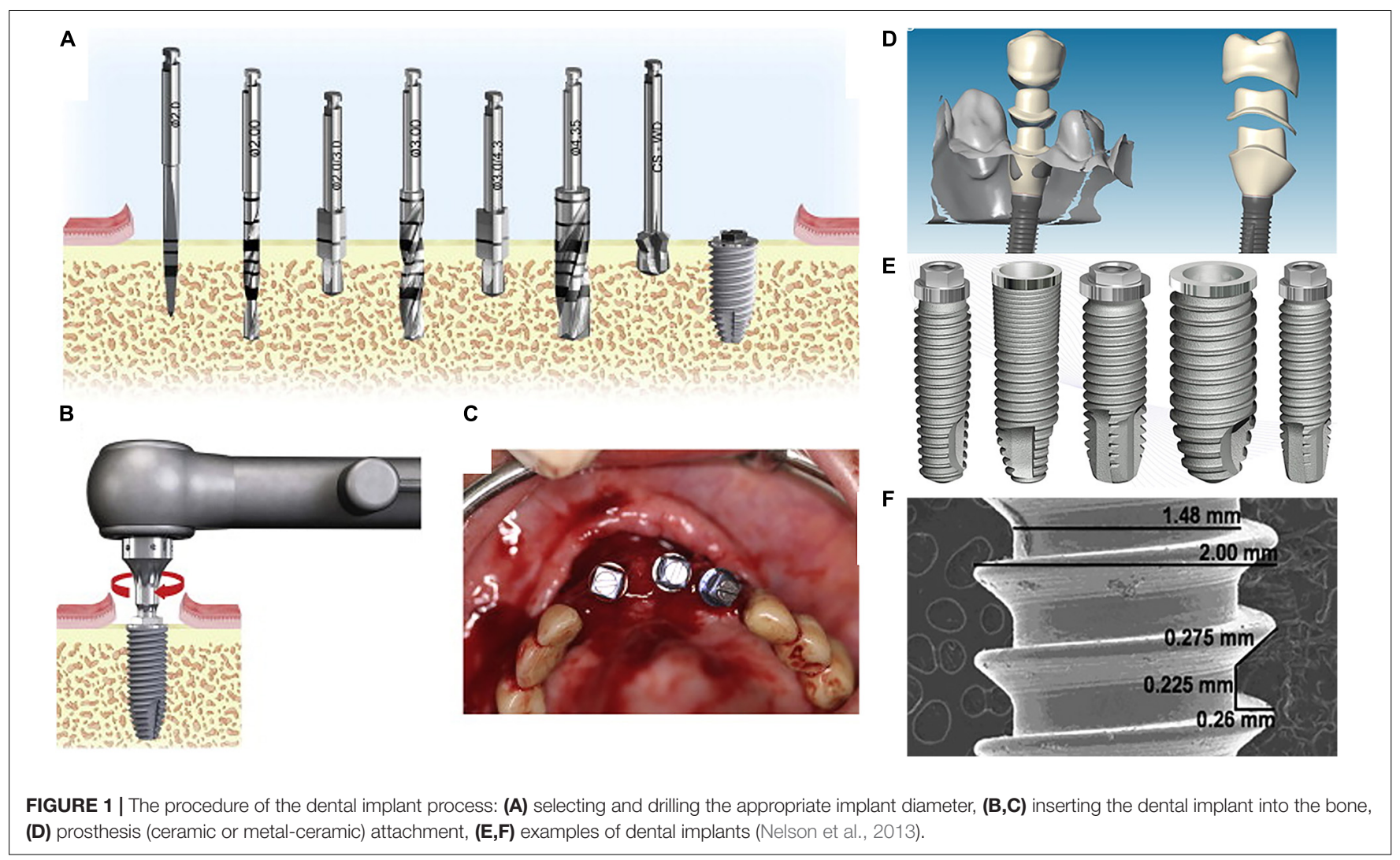

TABLE 1 | Various nanoparticles used in dental implants and their applications.

\begin{tabular}{|c|c|c|c|}
\hline Nanoparticle & Utilization method & Application & References \\
\hline \multirow{2}{*}{ Sliver } & $\begin{array}{l}\text { Coating of Sliver and amorphous nanoparticles of the } \\
\text { synthetic calcium phosphate. }\end{array}$ & Resin-composite fixatives & Cheng et al., 2012 \\
\hline & $\begin{array}{l}\text { Improved by chitosan with fluoride mixture, and placed as a } \\
\text { colloidal suspension yearly one-time. }\end{array}$ & Mouth-freshener & Dos Santos et al., 2014 \\
\hline & Coated with $\mathrm{Ca} / \mathrm{PO}_{4}{ }^{-}$ & Cement sealants & Osorio et al., 2014 \\
\hline & Inclusion into dental resins & Resins-composite fixatives & Kasraei et al., 2014 \\
\hline & Anti-bacterial agents for peri-implantitis & Treatments of antibacterial implant & Vargas-Reus et al., 2012 \\
\hline & Inclusion into dental cement & Dental cement & Guerreiro-Tanomaru et al., 2014 \\
\hline Titanium dioxide & In conjunction with bright-healing orthodontic paste & Resins composites fixatives & Poosti et al., 2013 \\
\hline \multirow[t]{2}{*}{ Chitosan-particles } & Combined with silver NPs. & Resins-composite fixatives & Targino et al., 2014 \\
\hline & $\begin{array}{l}\text { It's being used as a chelating agent in a } \\
\text { nano-hydroxyapatite-coated Ti implant. }\end{array}$ & Implants & Kim et al., 2013 \\
\hline \multirow[t]{2}{*}{ QAC nanostructures } & $\begin{array}{l}\text { Coated as a quatemarian ammonium compound with an } \\
\text { organosilane, silicon NPs, and epoxy silicate }\end{array}$ & Resins composite fixatives & Gong et al., 2014 \\
\hline & $\begin{array}{l}\text { Resin composite materials as a cross-linking quatemary } \\
\text { ammonium polyethyleneimine (QPEI) }\end{array}$ & Resins composite-materials & Beyth et al., 2010 \\
\hline
\end{tabular}


TABLE 2 | The evolution of dental implant materials and procedures.

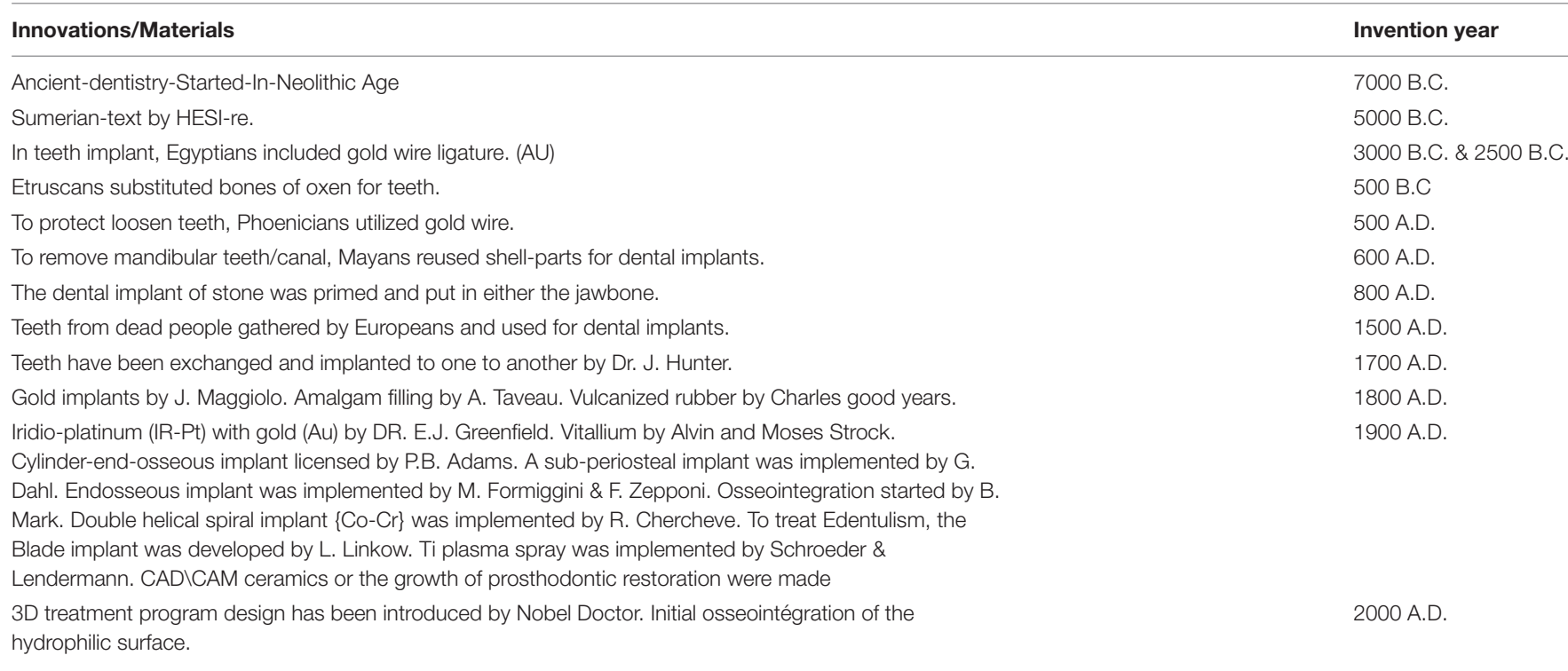

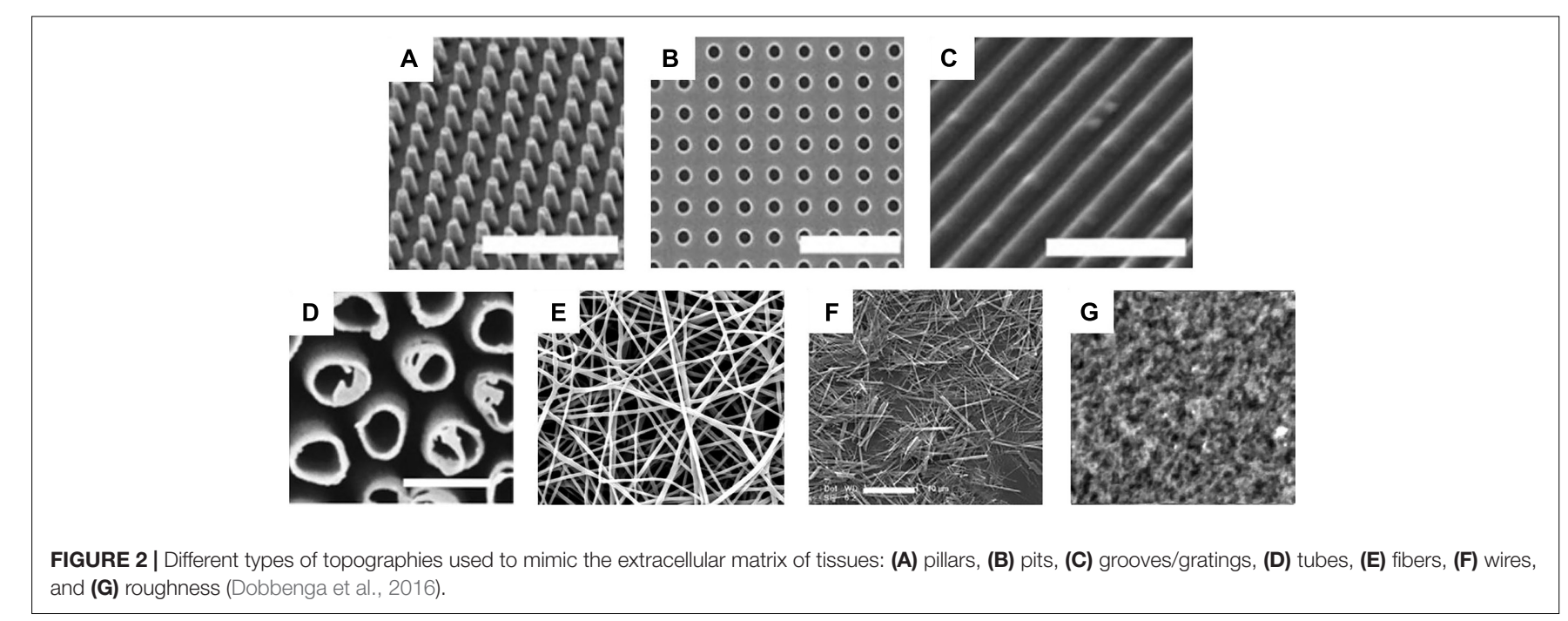

superimpose a high density of nanostructure onto Ti substrate. They reported the nanostructures alone may regulate osteoblast proliferation, however, the combination of micro-/submicroscale surface roughness had a positive effect on cell differentiation and local factor production through mimicking bone hierarchical complexity to improve in vivo implant osseointegration.

\section{MATERIALS UTILIZATION IN DENTAL IMPLANTS}

In the past decade, dental implants have seen substantial changes, with osseointegration being the main challenge because the metals vary in their properties from those of the human body. It was shown that alumina implants act as an inflammatory reaction generator which can decrease the adequate biological enclosures and causes clinical failure, and excessive surface microporosity in the proximity of the gingival cuff (Zheng et al., 2012), polymer-based implants such as missing dental roots and implants have been created to be substituted ( $\mathrm{Hu}$ et al., 2012). In this case, the requisite antimicrobial and osteogenic effects can emerge from the nanostructured surface of synthetic dental treatment. The necessary antibacterial and osteogenic effects can be attained by the nanosized surface of hybrid dental implants for instance Ti gelatine-gold nanocomposite surfaces enhance the biocompatibility of the dental implants (Lee et al., 2010), caused by the interaction of the cell survival, signal pathway, and cell adherent molecules in vitro. Nanostructured material forms are located on certain body interfaces so the biomaterial is surrounded by fibrous capsules. At present, some implant materials are used in clinical, for instance, stainless steel, Co-based alloys, titanium alloys, dense HA ceramics, and bio-glasses (Kaur and Singh, 2019). The tensile strength of dense HA ceramics $(70-150 \mathrm{MPa})$ is closest to that of cortical 
bone (40-100 MPa). The yield strength of these biomaterials is much higher than that of cortical bone (30-70 MPa). Although these mechanical properties match or even outperform human bone, the elastic modulus of biomaterials is higher than that of bone (15-30 MPa), which leads to the stress shielding effect. Besides, high modulus, low corrosion resistance, and allergic reaction of stainless steel limit the application range. Cobaltbased alloys have biological toxicity and high construction cost. The shortcoming of titanium alloys is low wear resistance. Magnesium alloys have low corrosion resistance and easy to degrade. Thus, they are not a suitable choice. New biomaterials are being developed to improve the problems of implant materials. The novel implant material needs to satisfy the following characteristics: high strength and toughness, excellent corrosion and wear-resistant, great biocompatible and bioactive, and can survive long-term without failure. The mechanical properties can be improved by controlling microstructure and element composition. Lots of researchers focus their studies on the effects of different substances, interface, and surface conditions on the osseointegration of dental implants (Wang et al., 2020b).

\section{THE NECESSITY OF NANO-SCALE MODIFICATION}

When a synthetic drug or substance is inserted into the body, tissue displays rapid reactions to the implant, based on the type and topography of the tissue, since bio-inert materials (i.e., Ti, stainless steel, etc.) have limited interactions with the surrounding tissue (bonding), certain bioactive coatings can be used to produce an interfacial chemical bond between the implant materials and surrounding bone tissues via biophysically and biochemically reaction (Zafar et al., 2019). Recently, fabricating nano-scale structures is an appropriate strategy to achieve the bone integration effect. On one hand, nanoparticles release the functional ions rapidly than other scale particles to obtain a quick response. On the other hand, nanoparticles are better absorbed by the tissue surrounding bone. Nanomaterials are promising vehicles to transport agents, which have different biomedical properties that affect their interactions with their biological environments and delivery destinations. For example, a bioactive nano carbonate coating on a dental implant that is near to the bone causes an ion reaction between the certain implant and the surroundings of body fluids. Furthermore, bioactive substances tend to speed up osseointegration when it is inserted into the human body of materials like tricalcium phosphate and polylactic-polyglycolic acid copolymers (Poon et al., 2020).

\section{MODIFICATION TECHNOLOGIES}

During the development of a new implant to reduce failure and improve adherence, the implant must be integrated with the tissue since it is a very crucial phenomenon in controlling the surface and bulk material properties and interfacial reactions. In this regard, nanotechnologies for the surface alteration of dental implants are extensively utilized, Ti surface nanomodification ensures strong bone-implant contact (BIC), osseointegration, and bone development (Salou et al., 2015), $3 \mathrm{D}$ nanostructures enhanced in vitro osteogenesis attachment, growth, and differentiation (Kurella and Dahotre, 2006; Bose et al., 2009). There are different surface modification technologies to promote osteogenesis attachment, growth, and differentiation, respectively. HA nanocrystalline surfaces produced by plasma spraying enhances adhesion to the osteoblast. HA has the largest capacity of adsorbing proteins among the calcium phosphates (li Yang et al., 2009). Although short-term animal studies have reported that plasma-sprayed HA-coated implants led to faster bone ingrowth, reports from long-term researches have been less encouraging. Because plasma-spraying method during treatment produced high temperature, which changed HA structure and resulted in poor adhesion between the coatings and substrates (li Yang et al., 2009). The hardness of HA coating was $44.35 \mathrm{MPa}$. The scratch resistance of incorporation of $\mathrm{TiO} 2$ with the hardness of $956 \mathrm{MPa}$ into HA increased by $36 \%$ (Azari et al., 2019). Nanocrystalline HA covering fabricated by sputtering deposition induces a fast growth and bone mineral recrystallization (SD). Moreover, the topography of biomechanical fixation and early implantation BIC has improved. Furthermore, the bone-to-implant adhesion can be enhanced by acid etching, ion-beam assisted deposition, and grit blasting leading to early biomechanical fixation (Coelho et al., 2010; Shibli et al., 2010). Nano-porous surfaces made by anodization techniques are beneficial for osteoblast-material interactions since they induce greater roughness values, low contact angle, and better superficial surface energy (Das et al., 2009; Von Wilmowsky et al., 2009). Also, lots of advantages can be attained by the micro-arc oxidation (MAO) technique which leads to enhanced bioactivity on Ti surfaces (Yao et al., 2010), also sol-gel-derived HA nanofibers combined with electrospinning facilitated the development of human osteoblasts. The roughness of crystalline HA increased ( $\mathrm{Ra}$ from 19.6 to $162.7 \mathrm{~nm}$ ) with higher temperatures of calcination from 200 to $1,200^{\circ} \mathrm{C}$ (Bajgai et al., 2010). The enhanced osteoblast distribution and activation can also be reached by chemical vapor deposition (CVD), such as the mineralizing surface of nanocrystal diamond coatings (Amaral et al., 2008). Compared with the blank control group, nanocrystal diamond coatings induced osteoblastic cell proliferation, which showed bioactive behavior through ALP activity and production of a mineralized matrix. The growth rate presented by MG63 and bone marrow cells were higher than the blank control group. In addition, the $\alpha, \omega$-diphosphonic acids are efficient for osteoblast interaction and proliferation. The nanofiber structure of the Ti surface is a better apatite-inductive than the nano-porous structures or nanoplate region formation by alkali hydrothermal treatment (Wang et al., 2008).

\section{NANO-SCALE SURFACE MODIFICATION TECHNOLOGIES}

The nano-scale surface modification techniques include anodization, acid treatment, alkali treatment, hydrogen peroxide 
chemical etching, sol-gel process, CVD, etc. These surface treatments can help to remove the biochemically defective bacteria inside the oral cavity and oxidize salivary molecules (Hannig et al., 2007; Hannig and Hannig, 2010). By fabrication of nanostructures through surface modification techniques, it will be possible to attain the easy-to-clean surface topography on the tooth surface. Surface modification technologies (for instance, plasma-spraying, acid-etching, anodization, or calcium phosphate) were applied in dental implants, which proven clinical efficacy (>95\% over 5 years) (Le Guéhennec et al., 2006).

\section{Anodization}

The anodization process is a mature technology to change the roughness and topographic features on the surface of $\mathrm{Ti}$ with many controllable parameters, such as oxidation duration, oxidation voltage, electrolyte solution type, and electrolyte solution concentration. The anodic oxide layer is formed by the charging of the double electric layer at the metal-electrolyte interface. The mechanism involves the dissolution of oxide film assisted by the electric field, producing a soluble salt containing the metal cation and an anion in the electrolytic bath. Anodization has been used to fabricate nanotubes on $\mathrm{Ti}$ implant surfaces with less than $100 \mathrm{~nm}$ diameter and a thickness of about a few hundred nanometers up to a few microns. This electrochemical deposition process performed in an electrolyte is called anodization or anodic oxidation. The results of surface modification on dogs and rabbit models show that the bone contact is much higher with better biomechanical torque removal values for the anodized surfaces than the original surfaces (Sul et al., 2002). Figure 3 summarizes the Gingival fibroblast (GF) adhesion and alignment along the nanopores, signifying strong mechano-stimulation from the nano-engineered abutment for orchestrating soft-tissue healing.

\section{Acid Etching}

Grains and grain boundaries can be distinguished by acid etching on the surface of the implant. The affecting parameters are bulk content, the surface microstructure, surface contamination, acid type and time of swallowing, selective substance removal, and the roughness, surfaces with the standard ( $\mathrm{Sa}$ ) values between 300 and 1,000 $\mathrm{nm}$ are usually known to be minimally rough. The surface layer has been studied little but optimistically, the existence of hydrogen ions in the acid may theoretically contribute to a $\mathrm{Ti}$ hydride layer (Palmquist et al., 2010). Histological images with fluorescent double-labeling revealed the deposition of newly formed bone around implants and endosteum of bone tissue. Fluorescent labels around Ti-Ca by acid etching process were more obvious than other kinds of the implant (Figure 4). The Ti oxide can formulate with 20$100 \mathrm{~nm}$ diameter and with thickness around $10 \mathrm{~nm}$, and formed by various $\mathrm{Ti}$ grades like $\mathrm{Ti6} \mathrm{Al} 4 \mathrm{~V}$ and also Cr-Co-Mo alloy, using high concentrated acids and bases (Variola et al., 2008). Sandblasting/acid-etching implants existed in contrast with the implants in machining or acid-etching, they have superior bone anchorage because torque removal values in a sandblasting/acidetched surface implant had been greatly improved (Li et al.,
2002). $\mathrm{H}_{2} \mathrm{O}_{2}$ was shown to be used in the implant surfaceetching to produce $\mathrm{TiO}_{2}$. The $\mathrm{H}_{2} \mathrm{O}_{2} / \mathrm{HCl}$ passive $\left(30 \%\right.$ of $\left.\mathrm{HNO}_{3}\right)$ surface treatment and thermo-treated surface therapy improved the adsorption on the surface of RGD cell-adhesive peptides (Wang et al., 2002; Mante et al., 2004). In sandblasting and $\mathrm{H}_{2} \mathrm{O}_{2}$ processing with micro/nanostructured Ti implants (Xie Y, et al., 2017), reactive oxygen species can be found in the surface of the implant and lead to severe wettability values and increase cell segregation and gene expression. Treatment of the implant with $\mathrm{HF}$ produces discreet $\mathrm{TiO}_{2}$ grit-blasted nanostructures (Ellingsen et al., 2006), but a careful test may be needed for complex chemical changes caused by induced acid treatments (Nazarov et al., 2017).

\section{Alkali Surface Treatment}

Alkali treatment is a usual surface treatment method in dentistry. In the in vitro test, alkali-treated Ti surfaces showed the ability to stimulate mineralization upon soaking in simulated body fluid (SBF) (Figure 5). Ti nanostructures can be further treated with sodium titanate gel coating outside the surface after $\mathrm{NaOH}$ treatment, a Ti gel layer is formed by $\mathrm{H}_{2} \mathrm{O}_{2}$. Also, $\mathrm{HA}$ deposition resulted in the formation of a coating on the surface of the dental implant. This behavior has also been seen in other metals such as zirconium and aluminum (Zhou et al., 2007). Alkali treatment helps in the growth of a nanosized and bioactive sodium titanate coating on implant surfaces. The CaP crystals may be nucleated on the bioactive surface when immersed in simulated body fluid (Kim et al., 2000). The activation of sodium titanate $\mathrm{Na}$ ions contributes to the formation of $\mathrm{Ti}-\mathrm{OH}$ by means of ion exchange. The negative $\mathrm{Ti}-\mathrm{OH}$ reacts with $\mathrm{SBF} \mathrm{Ca}^{+2}$ to produce Ti calcium. $\mathrm{P}$ and $\mathrm{Ca}$ ions can produce in the apatite crystals with calcium titanate that can facilitate appropriate conditions for cell differentiation of the bone marrow (Yang et al., 2017). Apatite formation is due to Ti neutral surface charge and produces mainly because of variable $\mathrm{pH}$ values (Pattanayak et al., 2012). Ti surfaces have evoked strong bone formation with either acid or alkaline therapy around the Ti implant. These data can be used in the future to advance research into biomaterials for bone implants.

\section{Sol-Gel Technique}

One of the major advantages of wet chemical deposition includes simple installation, moderate factors for chemical preparation, and the possibility to coat implants with complex 3D structures (Bosco et al., 2012). One of the coating techniques employed for effective osseointegration is biomimetic modification, classical biomimetic coating, such as Ca-P, usually requires a 14-28 days immersion period with SBF refill. Apatite surfaces developed biomimetically, such as rough and porous apatite layers that are deficient in calcium, can be used to promote cell adhesion and initial bone re-growth. As shown in Figure 6, in vitro osteoblast cultures on the sol-gel sprayed coatings showed that HA coatings by sol-gel enhanced cellular proliferation than that by plasma sprayed. Further better planning of bone formation, during sintering, sol-gel process techniques produce cellular stages of coating, including dipping and spinning coatings. It appears to apply to substrates in complicated geometry which can be 
A
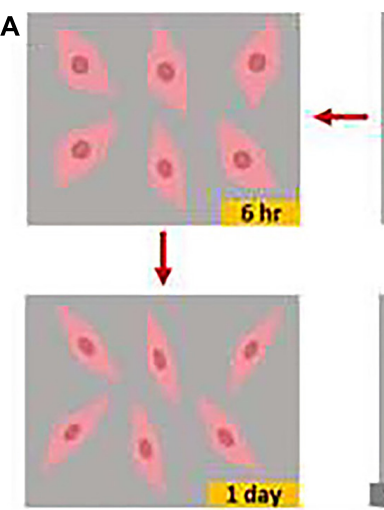

1 day

C

Aligned Tio, Nanopores

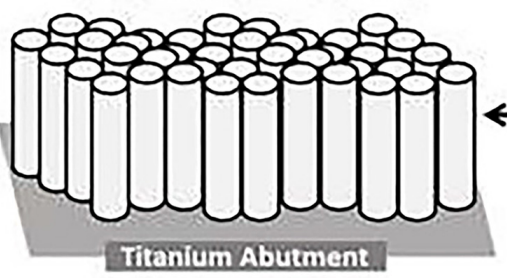

B
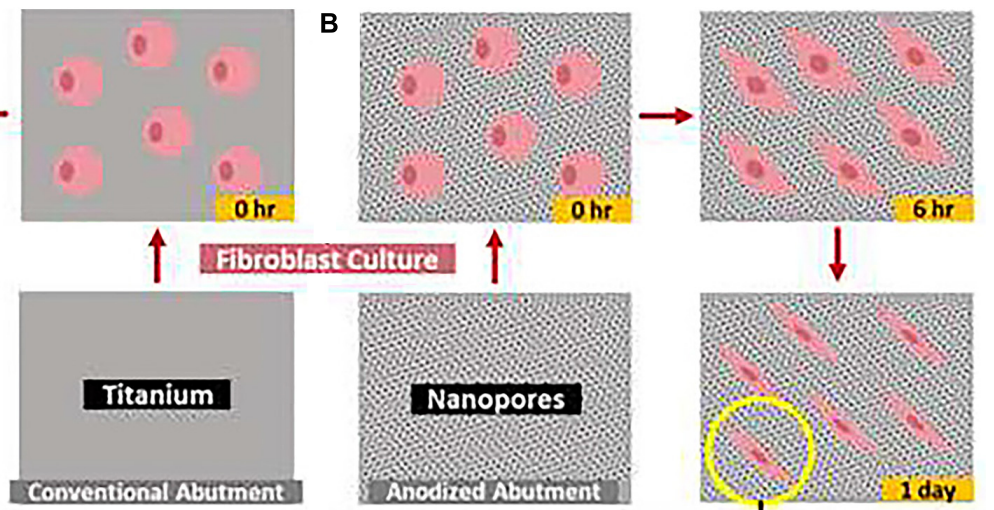

Ancarted Abotinent
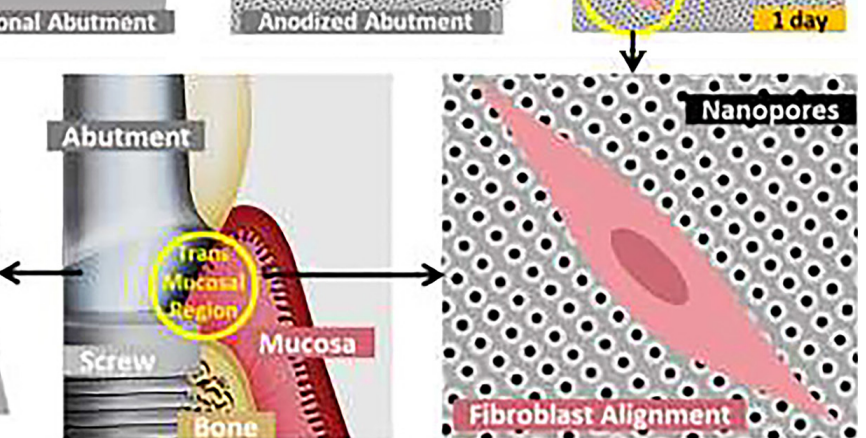

FIGURE 3 | Schematic representation of the nano-engineered titanium abutment with aligned $\mathrm{TiO}_{2}$ nanopores/nanotubes toward augmented fibroblast attachment and aligning. Time-dependent attachment and spreading of fibroblasts on (A) conventional abutment and (B) electrochemically anodized abutment with aligned nanopores, (C) the proposed application of aligned nanopores toward augmenting the adhesion and alignment of fibroblasts at the transmucosal abutment-mucosa interface (yellow circle) (Gulati et al., 2020).

used to deposit a wide range of metal oxides on metallic and non-metallic substrates. Methods of sol-gel accomplish the deposition on the surface of the implant of calcium phosphate nano-meter scale. The base can be mounted on the surface of the substratum using various techniques like dip-coating, spincoating, or spraying. After the drying process, only the precursor materials are attached to the target surface and shaped like a thin layer in gel shape (Paital and Dahotre, 2009).

\section{Chemical Vapor Deposition}

The chemical vapor deposition (CVD) method can deposit a layer on the substratum using chemical interaction only, while the physical vapor deposition (PVD) method requires mechanical forces. The CVD method can be useful when graphene (Gp) is used in dental implant coatings in vitro. A study has shown that Gp coated copper foils with the CVD method could drive dental pulp stem cells (DPSC) to deposit as a mineralized matrix without the use of osteogenic medium or chemical inducers. The higher absorbances observed in the experimental group confirmed that Gp can induce DPSC to spontaneously secrete the mineralized matrix (Figure 7). Also, CVD can be useful on Ti surfaces in dental implants with diamond nanoparticles it shows ultra-high hardness, improved strength, and adhesion. The CVD method can be utilized to fabricate nanoscale-modified bio-metal surfaces. It is known as one of the coating techniques for efficient development. The $\mathrm{CaP}-\mathrm{O}$ bio-ceramic nano-coating can be deposited on Ti-based dental implant by the CVD method, the CaP-O bio-ceramic nanostructured coatings on metals not only enhance bone connection but also improve abrasion, bond resistance, and dissolution rate. In addition, the CVD method can be used with metal-ceramic coatings. It provides a distinct pattern from a metallic nanocrystalline association at functionality to its tough-ceramic interaction upon the metallic surface.

\section{INFECTION TREATMENT}

Infections are the root cause of tooth implant failures and antibiotics are the key medication for this issue. Infections are the root cause of tooth implant failures and antibiotics are the key medication for this issue. However, antibiotic resistance is a global challenge to human health, which causes bacterial infections treatment to become more difficult. The Mechanoantibacterial effect can avoid the issues, which are well-known and are used in dental implants among first test materials. Nanoparticles are essential to antimicrobial activity in their dimensions and shape. Nanostructure includes majority methods to fabricate physical patterns and surface features onto the surface. The physical attraction between the bacterial cell wall and the nanomaterial is the driving force of the mechanobactericidal action (Linklater et al., 2021). There are two mechano-antibacterial mechanisms during contact with bacterial membranes. The nano-structure induced stretching of the 

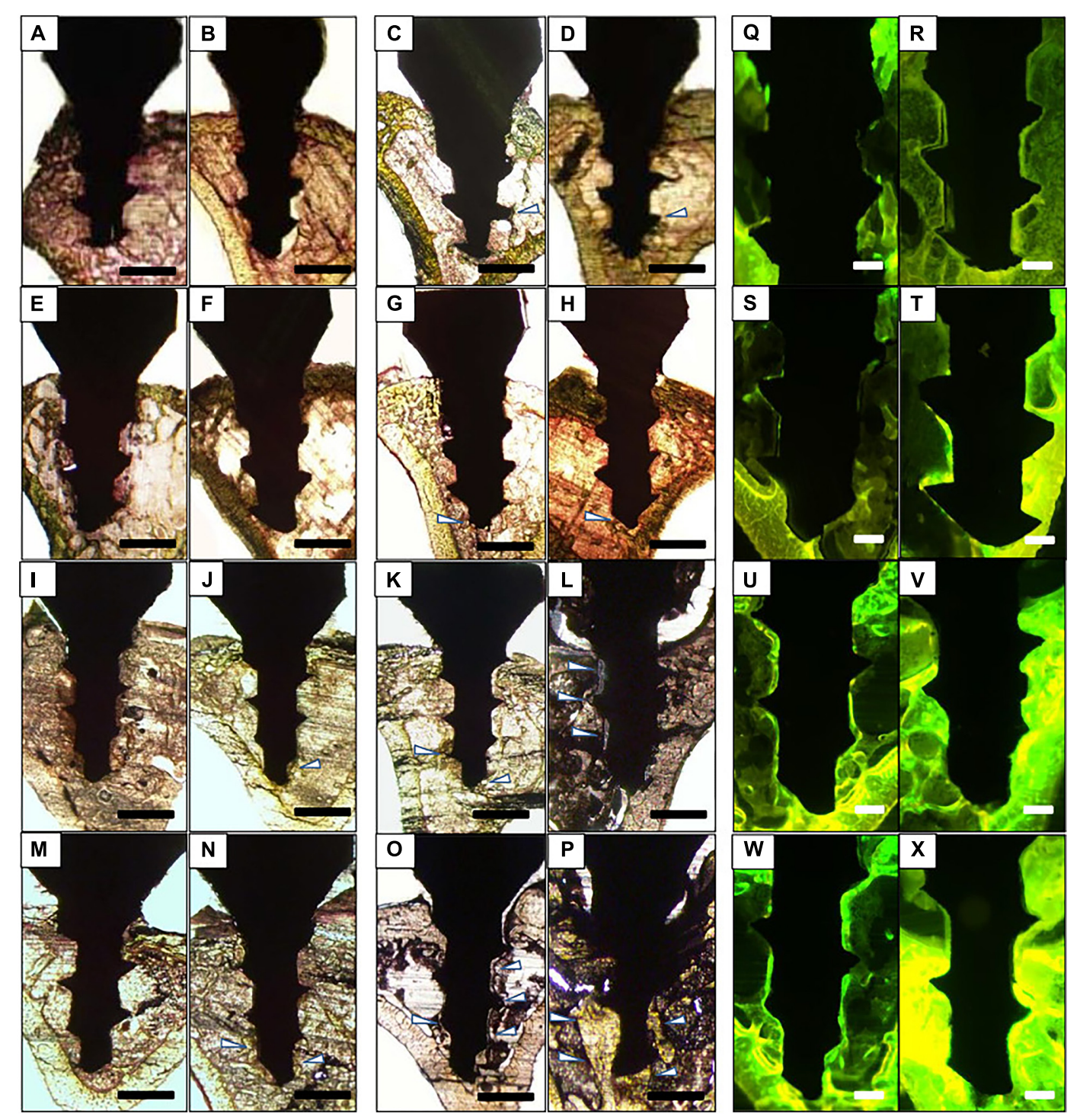

FIGURE 4 | Histology of bone formation around the implant surface. (A-P) Representative Villanueva osteochrome bone stain images of Ti (A-D), Ti-Ca (E-H), Ti-AE (I-L), and Ti-AE-Ca (M-P). (A,E,I,M) Show non-loaded implant 7 days after implantation, (B,F,J,N) show loaded implant 7 days after implantation, (C,G,K,O) show non-loaded 28 days after implantation, and (D,H,L,P) show loaded implant 28 days after implantation. Arrowheads indicate newly formed bone. (Q-X) Representative fluorescent microscopic images of implants and surrounding bone tissue. Sections of Ti (Q, R), Ti-Ca (S,T), Ti-AE (U,V), and Ti-AE-Ca (W,X) with surrounding bone tissue at 28 days after implantation. (Q, S,U,W) Show non-loaded implants, and (R,T,V,X) show loaded implants (Doe et al., 2020).

bacterial membrane between nanopillars or nanowires. And the sharp edges (e.g., graphene nanosheets) have a cutting effect on the bacterial membrane. A study fabricated the nanostructure on titanium supports by plasma etching or hydrothermal treatment, which produced obvious antibacterial behavior (Martel-Frachet et al., 2020). The reason was that randomly nanostructured surfaces with sharp nanosheet protrusions killed the bacteria by hydrothermal etching, and microscale two-tier hierarchical topography reduced bacteria attachment and rupture those bacteria membrane. The mechanisms of metallic's antibacterial properties are divided into three types (Marambio-Jones and Hoek, 2010). The bacteria absorb free metal ions followed by disruption of ATP production and DNA replication. Metal particles and metal ions generation of reactive oxygen species (ROS) damage to bacterial membranes. Besides, the abovementioned mechano-antibacterial mechanisms also play a vital role in the antibacterial process.

Additionally, the antibacterial coatings and antimicrobial molecules that are bound covalently to the surface of the implant are among the beneficial techniques. When the bacteria adhere to the surface of the implant, antibacterial substances naturally produce a preventative polysaccharide that results mostly in the decomposition of the biofilm which now acts as a shield to antimicrobial penetration and prevents the formation 


\section{Alkali-treated titanium surface promote in-vitro mineralization}
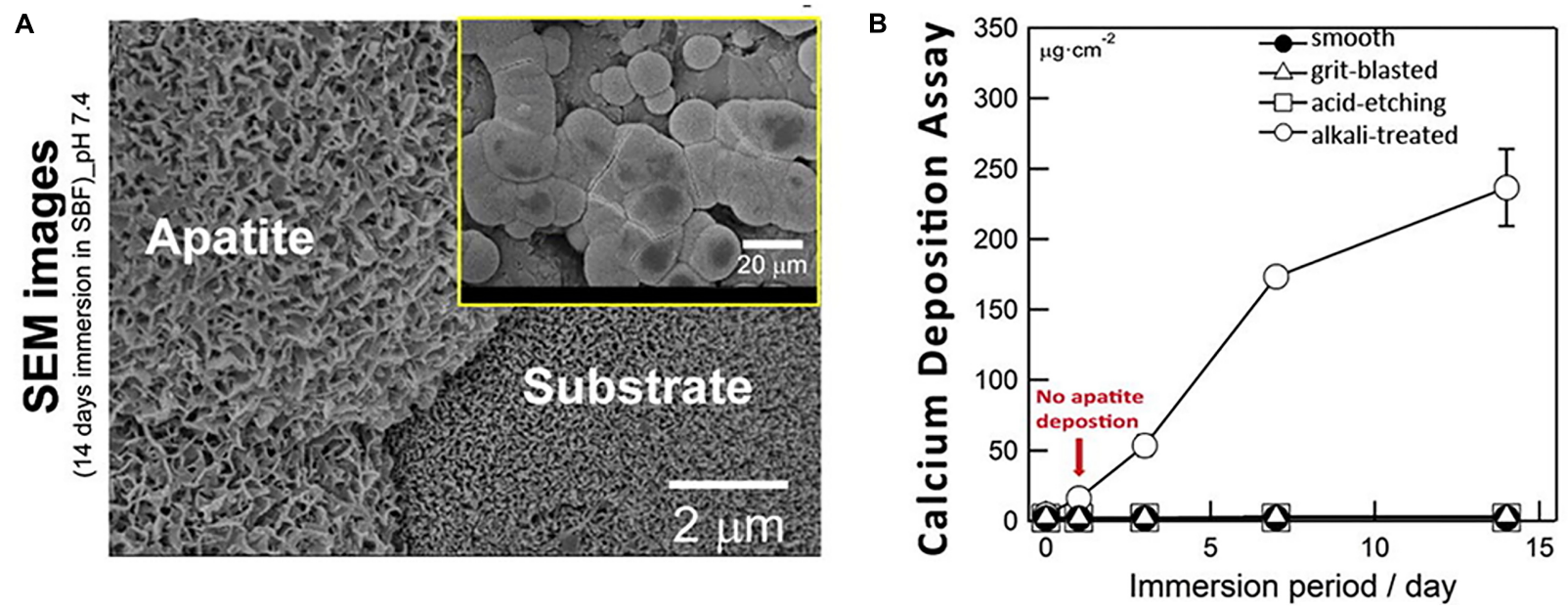

FIGURE 5 | (A) SEM images of all Ti disks with alkali-treated after immersion in SBF for 14 days and (B) The amount of calcium deposition onto all Ti disks with different surface treatments (untreated, grit-blasted, acid-etched, and alkali-treated) after immersion in SBF until 14 days (Camargo et al., 2017).

of infections, antibiotic resistance, and bacterial infections (Costerton et al., 1999; Donlan, 2001; Heuer et al., 2007).

\section{OSSEOINTEGRATION}

Brånemark has proposed the osseointegration phenomenon in 1985. Osseointegration is described as a systematic structural and functional interaction and integration between the live bone and the implant surface (Albrektsson and Sennerby, 1990; Li et al., 2020). Nanocomposite coating is essential for excellent osseointegration, inflammation, and osteolysis improvement (Choi et al., 2015). Due to their bioactivity and osteoconductive properties, $\mathrm{HA}$ and $\mathrm{CaP}$ are widely used to enhance $\mathrm{Ti}$ implant osseointegration (Barrère et al., 2003). Multiple studies have shown that $\mathrm{CaP}$ coatings produce calcium and phosphate ions and cause apatite precipitation as well as assisting the integration of biological systems including biological improvement parameters (Liu et al., 2005). Such deposition includes a cell adhesion substratum, osteoblast differentiation, and mineralized collagen synthesis, bone-tissue ECM, which eventually contributes to better osseointegration (LeGeros, 2002). Dental implants were also covered with molecules including fibronectin, collagens, Arginine-Glycine-aspartic acid to further strengthen the attachment of osteoblast cells (Bonfante et al., 2012). Activation of $\mathrm{TiO}_{2}$ to facilitate osteointegration of bone implants with vitamin B6 [pyridoxal 5'-phosphate (PLP)] is another way, PLP assists serum albumin and other plasma protein surface binding and produces a suitable medium for adherence to osteoblasts, delayed platelet activation, and blood clotting via its aldehyde community of ship-based formations (Lee et al., 2015). Ti implants functionalization in human pluripotent mediated progenitor-derived mesenchymal stem cells (iPSC-MP) enhances the growth of stem cells, influenced gene and differentiation production, and facilitated the development of alkaline phosphatase (Ingrassia et al., 2017). A new approach for bone regeneration is given in the combination with modified Ti and DPSCs (Yusa et al., 2016). Also, nanoscale osseointegration modulation could be led to the following incidents:

1. Adhesion to osteoblast and reduced fibroblast adhesion.

2. The regulation by anisotropy and dimensional nanostructures of cell activity (adhesive proliferation and differentiation).

3. Rapid cell distinction in the lineage of the osteoblast.

4. Improved activity and mineralization of alkaline phosphatases.

5. A drop- in nanostructured $\mathrm{ZnO}$ or $\mathrm{TiO}_{2}$ bacterial colonization.

6. Regulation and immunity response to protein adsorption.

\section{DENTAL IMPLANT DESIGN ESSENTIAL SPECIFICATIONS}

Evermore research on biomedical implants, process conditions, durability, biocompatibility, osseointegration, etc. are crucial matters in the development of modern dental implants. Implant efficiency and effectiveness in biological mediums will also need to be evaluated regarding chemical reactions, biocompatibility, etc. Biocompatibility can be divided into biological response and material response. The biological response includes blood response, immune response, and tissue response. The material reaction is mainly manifested in the change of physical and chemical properties. Osseointegration is considered as an acceptable contact between the dental implant and the surrounding tissue and is an important factor in implant design. Moreover, the wettability and surface roughness is based 

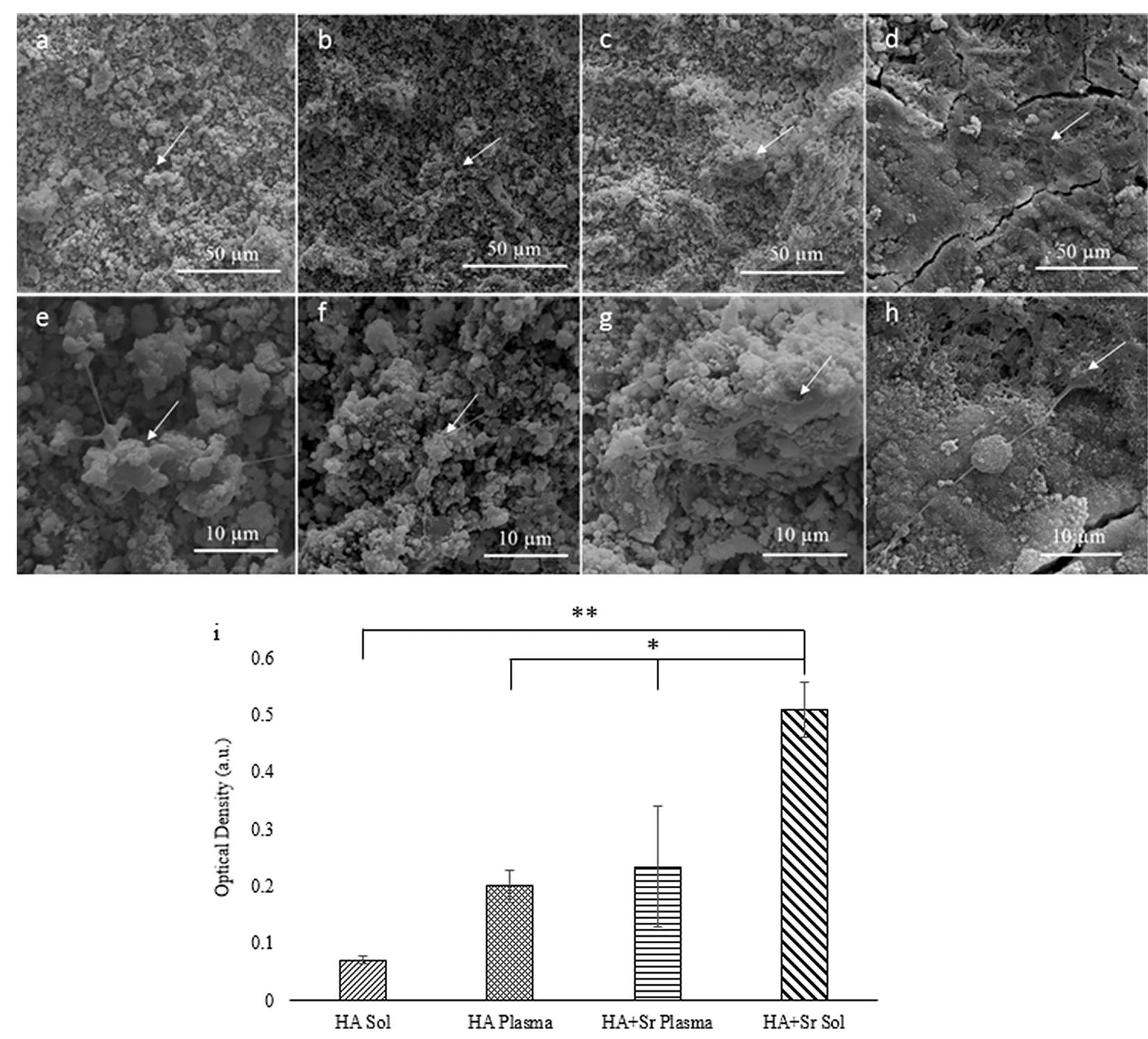

FIGURE 6 | SEM images of plasma sprayed HA and Sr-HA (a,b), and sol-gel coated HA and Sr-HA (c,d) at day 3 timepoint. Higher magnification of the area shown below for each respective coating (e-h). MTT data (i) for OB cultures on plasma and sol-gel coated HA and Sr-HA samples for the day 3 timepoint $\left({ }^{*} p<0.05\right.$,

${ }^{* *} p<0.01, N=3$ ) (Robertson et al., 2019).

on accelerating and enhancing osseointegration in the latest generation of dental implants (Ahmed et al., 2011).

\section{Wettability}

Surface with a wetting tension $>30 \mathrm{mN} / \mathrm{m}$ is defined as hydrophobicity, and $<30 \mathrm{mN} / \mathrm{m}$ is denoted hydrophilic, which affects the bio-response (Gittens et al., 2014). Considering the bio-response between human body fluids and cells on the implant surface, hydrophilic surfaces ranging from $40^{\circ}$ to $70^{\circ}$ water contact angle are suitable (Wang et al., 2020b). The horizontal surface modification and wettability can also determine surface topography weight because when the contact angle is varied, the implant's biosynthesis is affected by implant surface volume. The higher hydrophilic surface leads to increased contact with biological molecules and cells (Gittens et al., 2014). In comparison to conventional implants, dental replacements with highly hydrophilic as well as uneven surface interfaces are still the most appropriate candidates for osseointegration (Sawase et al., 2008). Considering their associations with cells and biological material, hydrophilic surfaces are usually considered ideal compared to hydrophobic surfaces (Allen, 1994). Lowered pollution of hydrocarbon was observed by increasing surface free energy and hydrophilicity by chemically modified Ti surfaces (Rupp et al., 2006). A nanocomposite coating significantly decreased biofilm accumulation at the surface of the implant, allowing a clean surface. It might allow isolating the salivary substances and adhesive microbes under the influence of mouth shearing forces nano-coating. 


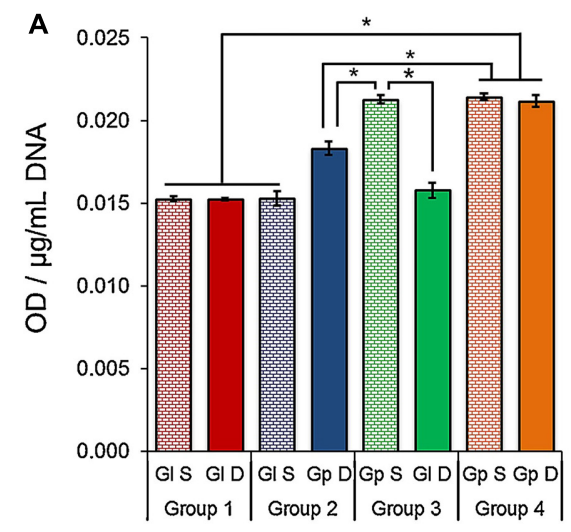

14 days

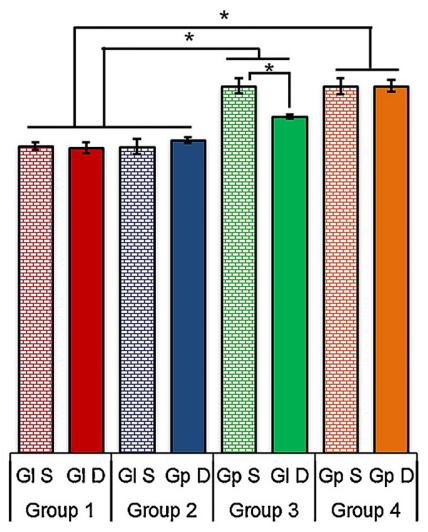

28 days

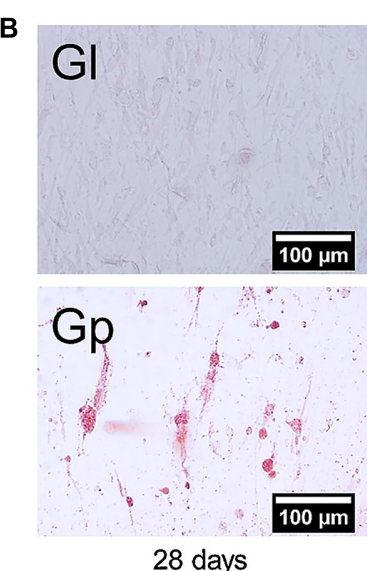

28 days

FIGURE 7 | (A) Alizarin red S staining. The media obtained from DPSC on Gp increased the mineralization of cells on Gl (Group 3) after 28 days ( $p<0.05)$. (B) Alizarin red S staining evinced the presence of calcium-rich deposits in the DPSCs cultured on Gp (28 days) (Xie H, et al., 2017$)$. ${ }^{*}$ Indicates $p$-value threshold for a statistical significance $p<0.05$.

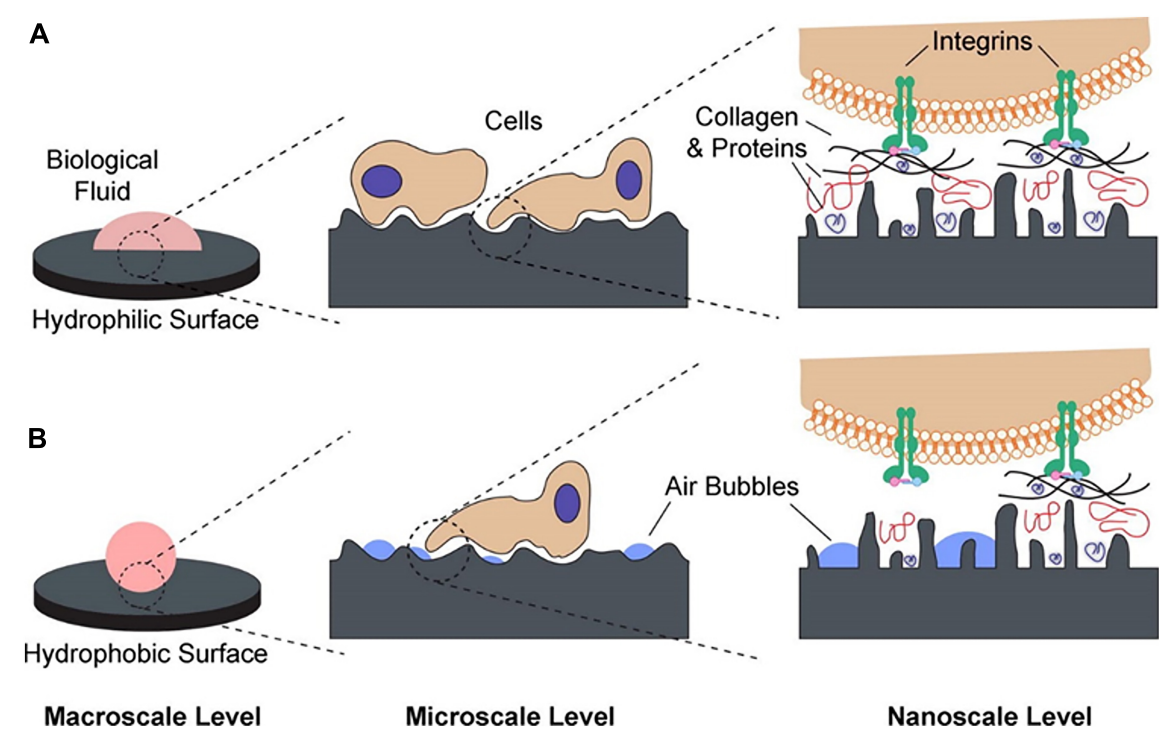

FIGURE 8 | Schematic of the possible interactions at different length scales: (A) hydrophilic surfaces interact closely with biological fluids, allowing normal protein adsorption to the surface and subsequent interactions with cell receptors and (B) hydrophobic surfaces are prone to hydrocarbon contamination, leading to entrapment of air bubbles that can interfere with protein adsorption and cell receptor adhesion/activation (Gittens et al., 2014).

Generally, wettability is low on the microstructured surfaces, created by anodization, etching, alkali surface treatment, solgel, and CVD techniques. The presence of micro and nanoscale structures might also modulate wettability and the biological response (Figure 8), however, many systems need further data on wettability.

\section{Surface Roughness}

Suitable surface roughness not only can promote mechanical interlocking but also can reduce the risk of peri-implantitis and ionic leakage. A moderate roughness of 1-2 $\mu \mathrm{m}$ may arrive at the balance of these two factors (Le Guéhennec et al., 2006). The surface topographies have been examined extensively in order to identify its effects on osseointegrations and the functional integrity of dental implants (Werner et al., 2009). A key function in implant quality is the effect of surface roughness on gene regulation and adjacent skeletal surface reactions (Boyan et al., 1999). Hence, increasing the implant surface with nanoroughness is needed to provide several binding points for cell attachment that result in success and facilitate the high-speed osseointegration (Jayaraman et al., 2004; Lim et al., 2004). Surfaces with nano type have a wider area to provide the underlying tissue with a firmer mechanical bond (Stokholm et al., 2014). Surface roughness facilitates focal adherence and serves as a reference in the structure and morphology of cytoskeletal, membrane receptor, and cell-type multiplication (Stevens and George, 2005; Choi et al., 2007). The adsorption of extracellular matrix molecules, such as fibronectin and 
albumin adsorption, was improved in vitro results on rough implant surfaces. Nanostructures like nanofibers, sharp tips, and nanotubes interfere within cells, influencing the distribution of cells (Park et al., 2007; Zafar et al., 2020). Fibroblast is better on smooth surfaces, builds upon smooth surfaces, and avoids rough surfaces. The relatively rough surfaces have more potential to proliferate osteoblast and collagen than others (Wennerberg, 1998), the nanoscale topographies have altered the adherence, proliferation, distinction, and growth of the matrix (Mustafa et al., 2001). Over-regulation of osteoblast proliferation is known upon this surface of nanoscale metals, such as $\mathrm{CaP}, \mathrm{Al}_{2} \mathrm{O}_{3}$, and Ti (Webster et al., 2001). Nanoscale implant surface alteration can alter the reactivity of the surface (Ward and Webster, 2006). The measurement of the optimal surface area for substances in a biological setting with an adhesive interface is an important issue in tissue technology (Toljanic et al., 2016). Such various changes, which resulted in a range of various chemicals and surfaces, often led to different reactions from biological molecules and osteoblast cells (Khang et al., 2008). Various medical analyses have already been carried out to assess the effect on stem cell differentiation of implant surface topography. The Ti $30 \mathrm{~nm}$ nanopores promise early delineation of osteoblastic substances and rapid osseointegration of human mesenchymal Ti implants. Increased proliferation and segregation of human mesenchymal stem cells (HMSCs) by developing micro and nano topographies were observed in $\mathrm{Zr}$ and $\mathrm{Ti}$ (Lavenus et al., 2011; Perrotti et al., 2013; Hirano et al., 2015).

\section{SUMMARY AND FUTURE RESEARCH}

The main cause of dental implant failure is the chronic inflammation and infections around implants and osseointegration issues. Expect for metal implants, non-metallic substitutes can be used as the root of the teeth (e.g., bioceramics, bio-glasses, polyetherketoneketone (PEKK)) (Najeeb et al., 2016; Baino and Verné, 2017; Skallevold et al., 2019; Alqurashi et al., 2021). Nanotechnology can manufacture highefficiency and low-cost implant materials with bioactivity and

\section{REFERENCES}

Abraham, C. M. (2014). A brief historical perspective on dental implants, their surface coatings and treatments. Open Dent. J. 8, 50-55. doi: 10.2174/ 1874210601408010050

Ahmed, M., Omar, O., Xia, W., and Palmquist, A. (2011). Dental implant surfaces-physicochemical properties, biological performance, and trends, chapter 2, book. Implant. Dent. A Rapidly Evol. Pract. 19-56. doi: 10.5772/ 17512

Akbarian, S., Sojoodi, J., Monnavari, F., Heidari, H., Khosravian, P., Javar, H. A., et al. (2017). Nano conjugated PLGA-Chlorambucil: synthesis in vitro anti non- Hodgkin's Lymphoma cellular assay. Lett. Drug Des. Discov. 14, 827-836. doi: 10.2174/1570180814666161130113446

Alani, A., Kelleher, M., and Bishop, K. (2014). Peri-implantitis. part 1: scope of the problem. Br. Dent. J. 217, 281-287. doi: 10.1038/sj.bdj.2014.808

Albrektsson, T., and Sennerby, L. (1990). Direct bone anchorage of oral implants: clinical and experimental considerations of the concept of osseointegration. Parodontologie 14, 307-320.

Allen, K. W. (1994). Contact angle, wettability and adhesion. Int. J. Adhes. Adhes. 14:69. doi: 10.1016/0143-7496(94)90024-8 anti-infection, which is tending to multifunctional properties and efficient regulation of host response. However, researchers should select the composition of the layer carefully to determine the optimal threshold allowing cells to survive and bacteria to be killed. Because the metallic ions may have a toxic effect on the surrounding cells, the slow release of these functional ions may have both non-toxicity and long-term antibacterial function. Antibiotics have excellent antibacterial activity, but the increasing resistance of bacteria limits the development of antibiotics. Therefore, the organic antibacterial agent (e.g., chitosan, antimicrobial peptides) is also a suitable choice to overcome the main issues of antibiotics, which is currently under investigation (Spriano et al., 2018). Besides, nanotechnology has given new insights into the next generation of implants and nanostructure fabrication is a remarkable direction in dental implant development and also in bio-inspired technologies that mimic natural tissue and structures. Nevertheless, what must be paid attention to is there are still no standardized antibacterial implant methods and protocols both in vitro and in vivo for clinical use to satisfy the requirements. It is hard to contrast the results under different experimental conditions. Especially, lots of research require long-term in vivo experiments. Based on these factors, animals of different ages and species have been used for the estimation of biomaterials with different shapes and processes. Nowadays, there is still not unified quantification standard. Nowadays, it requires legal constraints in the future. This research paper seems to be inspiring and open new horizons in establishing a way toward de novo dental implant designs with multifunctional properties.

\section{AUTHOR CONTRIBUTIONS}

SK and SA: conceptualization. QW and ME: methodology. SK, SA, CG, and QW: investigation. FD: resources. ME and SL: data curation. FD and SA: supervision. All authors contributed to the article and approved the submitted version.

Alqurashi, H., Khurshid, Z., Syed, A. U. Y., Rashid Habib, S., Rokaya, D., and Zafar, M. S. (2021). Polyetherketoneketone (PEKK): an emerging biomaterial for oral implants and dental prostheses. J. Adv. Res. 28, 87-95. doi: 10.1016/j.jare.2020. 09.004

Amaral, M., Dias, A. G., Gomes, P. S., Lopes, M. A., Silva, R. F., Santos, J. D., et al. (2008). Nanocrystalline diamond: In vitro biocompatibility assessment by MG63 and human bone marrow cells cultures. J. Biomed. Mater. Res. A 87, 91-99. doi: 10.1002/jbm.a.31742

Andrade, A. O., Luna, A. V. L. I, Farias, A., Vasconcelos, M. G., and Vasconcelos, R. G. (2020). Passo a passo clínico dos laminados estéticos: uma alternativa restauradora em dentes anteriores. Arch. Heal. Investig. 8, 549-555. doi: 10. 21270/archi.v8i9.3231

Ansarian, I., Shaeri, M. H., Ebrahimi, M., and Minárik, P. (2019a). Tribological characterization of commercial pure titanium processed by multi-directional forging. Acta Metall. Sin. (English Lett.) 32, 857-868. doi: 10.1007/s40195-01900877-4

Ansarian, I., Shaeri, M. H., Ebrahimi, M., Minárik, P., and Bartha, K. (2019b). Microstructure evolution and mechanical behaviour of severely deformed pure titanium through multi directional forging. J. Alloys Compd. 776, 83-95. doi: 10.1016/j.jallcom.2018.10.196 
Attarilar, S., Djavanroodi, F., Irfan, O. M., Al-Mufadi, F. A., Ebrahimi, M., and Wang, Q. D. (2020). Strain uniformity footprint on mechanical performance and erosion-corrosion behavior of equal channel angular pressed pure titanium. Results Phys. 17:103141. doi: 10.1016/j.rinp.2020.103141

Attarilar, S., Salehi, M. T., and Djavanroodi, F. (2019). Microhardness evolution of pure titanium deformed by equal channel angular extrusion. Metall. Res. Technol. 116:408. doi: 10.1051/metal/2018135

Azari, R., Rezaie, H. R., and Khavandi, A. (2019). Investigation of functionally graded $\mathrm{HA}-\mathrm{TiO} 2$ coating on $\mathrm{Ti}-6 \mathrm{Al}-4 \mathrm{~V}$ substrate fabricated by solgel method. Ceram. Int. 45, 17545-17555. doi: 10.1016/j.ceramint.2019. 05.317

Baino, F., and Verné, E. (2017). Production and characterization of glass-ceramic materials for potential use in dental applications: thermal and mechanical properties, microstructure, and in vitro bioactivity. Appl. Sci. 7:1330. doi: 10 . 3390/app7121330

Bajgai, M. P., Parajuli, D. C., Park, S. J., Chu, K. H., Kang, H. S., and Kim, H. Y. (2010). Hydroxyapatite particulate nanofiber modified titanium: In-Vitro bioactivity. Bioceram. Dev. Appl. 1, 1-4. doi: 10.4303/bda/d110131

Barhoum, A., Samyn, P., Öhlund, T., and Dufresne, A. (2017). Review of recent research on flexible multifunctional nanopapers. Nanoscale 9, 15181-15205. doi: $10.1039 / \mathrm{c} 7 \mathrm{nr} 04656 \mathrm{a}$

Barrère, F., Van Der Valk, C. M., Meijer, G., Dalmeijer, R. A. J., De Groot, K., and Layrolle, P. (2003). Osteointegration of biomimetic apatite coating applied onto dense and porous metal implants in femurs of goats. J. Biomed. Mater. Res. B Appl. Biomater. 67, 655-665. doi: 10.1002/jbm.b.10057

Beyth, N., Yudovin-Farber, I., Perez-Davidi, M., Domb, A. J., and Weiss, E. I. (2010). Polyethyleneimine nanoparticles incorporated into resin composite cause cell death and trigger biofilm stress in vivo. Proc. Natl. Acad. Sci. U.S.A. 107, 22038-22043. doi: 10.1073/pnas.1010341107

Bhat, S., and Kumar, A. (2013). Biomaterials and bioengineering tomorrow's healthcare. Biomatterial 3:e24717. doi: 10.4161/biom.24717

Bonfante, E. A., Marin, C., Granato, R., Suzuki, M., Hjerppe, J., Witek, L., et al. (2012). Histologic and biomechanical evaluation of alumina-blasted/acidetched and resorbable blasting media surfaces. J. Oral Implantol. 38, 549-557. doi: 10.1563/AAID-JOI-D-10-00105

Bosco, R., Van Den Beucken, J. V., Leeuwenburgh, S., and Jansen, J. (2012). Surface engineering for bone implants: a trend from passive to active surfaces. Coatings 2, 95-119. doi: 10.3390/coatings2030095

Bose, S., Roy, M., Das, K., and Bandyopadhyay, A. (2009). Surface modification of titanium for load-bearing applications. J. Mater. Sci. Mater. Med. 20(Suppl. 1), S19-S24. doi: 10.1007/s10856-008-3418-1

Boyan, B. D., Sylvia, V. L., Liu, Y., Sagun, R., Cochran, D. L., Lohmann, C. H., et al. (1999). Surface roughness mediates its effects on osteoblasts via protein kinase A and phospholipase A2. Biomaterials 20, 2305-2310. doi: 10.1016/ S0142-9612(99)00159-3

Branemark, P. I. (1983). Osseointegration and its experimental background. J. Prosthet. Dent. 50, 399-410. doi: 10.1016/S0022-3913(83)80101-2

Brånemark, P. I., Breine, U., Johansson, B., Roylance, P. J., Röckert, H., and Yoffey, J. M. (1964). Regeneration of bone marrow. Cells Tissues Organs 59, 1-46. doi: $10.1159 / 000142601$

Burch, R. H. (1997). Dr. Pinkney Adams-a dentist before his time. Ark. Dent. 68, 14-15.

Camargo, W. A., Takemoto, S., Hoekstra, J. W., Leeuwenburgh, S. C. G., Jansen, J. A., van den Beucken, J. J. J. P., et al. (2017). Effect of surface alkali-based treatment of titanium implants on ability to promote in vitro mineralization and in vivo bone formation. Acta Biomater. 57, 511-523. doi: 10.1016/j.actbio. 2017.05.016

Catledge, S. A., Fries, M. D., Vohra, Y. K., Lacefield, W. R., Lemons, J. E., Woodard, S., et al. (2002). Nanostructured ceramics for biomedical implants. J. Nanosci. Nanotechnol. 2, 293-312. doi: 10.1166/jnn.2002.116

Chen, W., Li, W., Xu, K., Li, M., Dai, L., Shen, X., et al. (2018). Functionalizing titanium surface with PAMAM dendrimer and human BMP2 gene via layerby-layer assembly for enhanced osteogenesis. J. Biomed. Mater. Res. A 106, 706-717. doi: 10.1002/jbm.a.36273

Cheng, L., Weir, M. D., Xu, H. H. K., Antonucci, J. M., Kraigsley, A. M., Lin, N. J., et al. (2012). Antibacterial amorphous calcium phosphate nanocomposites with a quaternary ammonium dimethacrylate and silver nanoparticles. Dent. Mater. 28, 561-572. doi: 10.1016/j.dental.2012.01.005
Choi, A. H., Cazalbou, S., and Ben-Nissan, B. (2015). Nanobiomaterial coatings in dentistry. Front. Oral Biol. 17:49-61. doi: 10.1159/000381693

Choi, C. H., Hagvall, S. H., Wu, B. M., Dunn, J. C. Y., Beygui, R. E., and Kim, C. J. C. J. (2007). Cell interaction with three-dimensional sharp-tip nanotopography. Biomaterials 28, 1672-1679. doi: 10.1016/j.biomaterials.2006. 11.031

Coelho, P. G., Granato, R., Marin, C., Bonfante, E. A., Janal, M. N., and Suzuki, M. (2010). Biomechanical and bone histomorphologic evaluation of four surfaces on plateau root form implants: an experimental study in dogs. Oral Surg. Oral Med. Oral Pathol. Oral Radiol. Endodontol. 109, e39-e45. doi: 10.1016/j.tripleo. 2010.01.004

Coelho, P. G., Granjeiro, J. M., Romanos, G. E., Suzuki, M., Silva, N. R. F., Cardaropoli, G., et al. (2009). Basic research methods and current trends of dental implant surfaces. J. Biomed. Mater. Res. B Appl. Biomater. 88, 579-596. doi: 10.1002/jbm.b.31264

Cohen, A. S., Shen, T. C., and Pogrel, M. A. (1995). Transplanting teeth successfully: autografts and allografts that work. J. Am. Dent. Assoc. 126, 481-485. doi: 10.14219/jada.archive.1995.0211

Costerton, J. W., Stewart, P. S., and Greenberg, E. P. (1999). Bacterial biofilms: a common cause of persistent infections. Science 284, 1318-1322. doi: 10.1126/ science. 284.5418 .1318

Crabb, C. (2006). History of dental implants. Dent. Nurs. 2, 398-399. doi: 10.12968/ denn.2006.2.8.29896

Das, K., Bose, S., and Bandyopadhyay, A. (2009). TiO2 nanotubes on Ti: influence of nanoscale morphology on bone cell-materials interaction. J. Biomed. Mater. Res. A 90, 225-237. doi: 10.1002/jbm.a.32088

Davis, B. K. (2010). The role of technology in facial prosthetics. Curr. Opin. Otolaryngol. Head Neck Surg. 18, 332-340. doi: 10.1097/MOO. 0b013e32833bb38c

Derrick, D. D. (1986). Dentistry. An illustrated history. J. Dent. 14, 271-272. doi: 10.1016/0300-5712(86)90044-8

Dobbenga, S., Fratila-apachitei, L. E., and Zadpoor, A. A. (2016). Nanopatterninduced osteogenic differentiation of stem cells-a systematic review. Acta Biomater. 46, 3-14. doi: 10.1016/j.actbio.2016.09.031

Doe, Y., Ida, H., Seiryu, M., Deguchi, T., Takeshita, N., Sasaki, S., et al. (2020). Titanium surface treatment by calcium modification with acid-etching promotes osteogenic activity and stability of dental implants. Materialia 12:100801. doi: 10.1016/j.mtla.2020.100801

Dohan Ehrenfest, D. M., Coelho, P. G., Kang, B. S., Sul, Y. T., and Albrektsson, T. (2010). Classification of osseointegrated implant surfaces: materials, chemistry and topography. Trends Biotechnol. 28, 198-206. doi: 10.1016/j.tibtech.2009.12. 003

Donlan, R. M. (2001). Biofilms and device-associated infections. Emerg. Infect. Dis. 7, 277-281. doi: 10.3201/EID0702.700277

Dos Santos, V. E., Filho, A. V., Ribeiro Targino, A. G., Pelagio Flores, M. A., Galembeck, A., Caldas, A. F., et al. (2014). A new "silver-Bullet" to treat caries in children-nano silver fluoride: a randomised clinical trial. J. Dent. 42, 945-951. doi: 10.1016/j.jdent.2014.05.017

Ellingsen, J. E., Thomsen, P., and Lyngstadaas, S. P. (2006). Advances in dental implant materials and tissue regeneration. Periodontol. 2000 41, 136-156. doi: 10.1111/j.1600-0757.2006.00175.x

El-Maghrabi, H. H., Barhoum, A., Nada, A. A., Moustafa, Y. M., Seliman, S. M., Youssef, A. M., et al. (2018). Synthesis of mesoporous core-shell CdS@TiO2 $(0 \mathrm{D}$ and $1 \mathrm{D})$ photocatalysts for solar-driven hydrogen fuel production. J. Photochem. Photobiol. A Chem. 351, 261-270. doi: 10.1016/j.jphotochem. 2017.10.048

Espinosa-Cristóbal, L. F., Martinez-Castanon, G. A., Téllez-Déctor, E. J., NiñoMartínez, N., Zavala-Alonso, N. V., and Loyola-Rodríguez, J. P. (2013). Adherence inhibition of Streptococcus mutans on dental enamel surface using silver nanoparticles. Mater. Sci. Eng. C Mater. Biol. Appl. 33, 2197-2202. doi: 10.1016/j.msec.2013.01.039

Gittens, R. A., Mclachlan, T., Olivares-navarrete, R., Cai, Y., Berner, S., Tannenbaum, R., et al. (2011). The effects of combined micron-/ submicronscale surface roughness and nanoscale features on cell proliferation and differentiation. Biomaterials 32, 3395-3403. doi: 10.1016/j.biomaterials.2011. 01.029

Gittens, R. A., Scheideler, L., Rupp, F., Hyzy, S. L., Geis-gerstorfer, J., Schwartz, Z., et al. (2014). A review on the wettability of dental implant surfaces II: biological 
and clinical aspects. Acta Biomater. 10, 2907-2918. doi: 10.1016/j.actbio.2014. 03.032

Gonçalves, O. D., Egito, M., Castro, C., Groisman, S., Basílio, M., and da Penha, N. L. (2019). About the elemental analysis of dental implants. Radiat. Phys. Chem. 154, 53-57. doi: 10.1016/j.radphyschem.2018.03.014

Gong, S. Q., Epasinghe, D. J., Zhang, W., Zhou, B., Niu, L. N., Ryou, H., et al. (2014). Synthesis of antimicrobial silsesquioxane-silica hybrids by hydrolytic co-condensation of alkoxysilanes. Polym. Chem. 5, 454-462. doi: 10.1039/ c3py00635b

Greenfield, E. J. (1991). Implantation of artificial crown and bridge abutments. 1913. Int. J. Oral Implantol. 7, 63-68.

Guerreiro-Tanomaru, J. M., Trindade-Junior, A., Cesar Costa, B., Da Silva, G. F., Drullis Cifali, L., Basso Bernardi, M. I., et al. (2014). Effect of zirconium oxide and zinc oxide nanoparticles on physicochemical properties and antibiofilm activity of a calcium silicate-based material. Sci. World J. 2014:975213. doi: $10.1155 / 2014 / 975213$

Gulati, K., Moon, H.-J., Kumar, P. T. S., Han, P., and Ivanovski, S. (2020). Anodized anisotropic titanium surfaces for enhanced guidance of gingival fibroblasts. Mater. Sci. Eng. C 112:110860. doi: 10.1016/j.msec.2020.110860

Gupta, A., Dhanraj, M., and Sivagami, G. (2010). Status of surface treatment in endosseous implant: a literary overview. Indian J. Dent. Res. 21, 433-438. doi: 10.4103/0970-9290.70805

Hannig, M., and Hannig, C. (2010). Nanomaterials in preventive dentistry. Nat. Nanotechnol. 5, 565-569. doi: 10.1038/nnano.2010.83

Hannig, M., Kriener, L., Hoth-Hannig, W., Becker-Willinger, C., and Schmidt, H. (2007). Influence of nanocomposite surface coating on biofilm formation in situ, in: J. Nanosci. Nanotechnol. 7, 4642-4648. doi: 10.1166/jnn.2007.18117

Heuer, W., Elter, C., Demling, A., Neumann, A., Suerbaum, S., Hannig, M., et al. (2007). Analysis of early biofilm formation on oral implants in man. J. Oral Rehabil. 34, 377-382. doi: 10.1111/j.1365-2842.2007.01725.x

Hirano, T., Sasaki, H., Honma, S., Furuya, Y., Miura, T., Yajima, Y., et al. (2015). Proliferation and osteogenic differentiation of human mesenchymal stem cells on zirconia and titanium with different surface topography. Dent. Mater. J. 34, 872-880. doi: 10.4012/dmj.2015-129

Hu, H., Zhang, W., Qiao, Y., Jiang, X., Liu, X., and Ding, C. (2012). Antibacterial activity and increased bone marrow stem cell functions of $\mathrm{Zn}$-incorporated $\mathrm{TiO}$ 2 coatings on titanium. Acta Biomater. 8, 904-915. doi: 10.1016/j.actbio.2011. 09.031

Huang, L., Dai, T., Xuan, Y., Tegos, G. P., and Hamblin, M. R. (2011). Synergistic combination of chitosan acetate with nanoparticle silver as a topical antimicrobial: efficacy against bacterial burn infections. Antimicrob. Agents Chemother. 55, 3432-3438. doi: 10.1128/AAC.01803-10

Ingrassia, D., Sladkova, M., Palmer, M., Xia, W., Engqvist, H., and de Peppo, G. M. (2017). Stem cell-mediated functionalization of titanium implants. J. Mater. Sci. Mater. Med. 28:133. doi: 10.1007/s10856-017-5944-1

International ASTM (2014). Committee F42 on Additive Manufacturing Technologies. West Conshohocken, PA: ASTM International.

Jang, J. M., Kim, S. D., Park, T. E., and Choe, H. C. (2018). Ultra-fine structures of Pd-Ag-HAp nanoparticle deposition on protruded TiO 2 barrier layer for dental implant. Appl. Surf. Sci. 432, 285-293. doi: 10.1016/j.apsusc.2017.07. 114

Jastrzebska, A., Kaminski, A., Grazka, E., Marowska, J., Sadlo, J., Gut, G., et al. (2014). Effect of gamma radiation and accelerated electron beam on stable paramagnetic centers induction in bone mineral: Influence of dose, irradiation temperature and bone defatting. Cell Tissue Bank 15, 413-428. doi: 10.1007/ s10561-013-9406-9

Jayaraman, M., Meyer, U., Martin, B., Joos, U., and Wiesmann, H. (2004). Influence of titanium surfaces on attachment of osteoblast-like cells in vitro. Biomaterials 25, 625-631. doi: 10.1016/S0142-9612(03)00571-4

Jeevanandam, J., Barhoum, A., Chan, Y. S., Dufresne, A., and Danquah, M. K. (2018). Review on nanoparticles and nanostructured materials: history, sources, toxicity and regulations. Beilstein J. Nanotechnol. 9, 1050-1074. doi: 10.3762/ bjnano.9.98

Jin, Q. M., Zhao, M., Webb, S. A., Berry, J. E., Somerman, M. J., and Giannobile, W. V. (2003). Cementum engineering with three-dimensional polymer scaffolds. J. Biomed. Mater. Res. A. 67, 54-60. doi: 10.1002/jbm.a.10058

Kaminski, A., Grazka, E., Jastrzebska, A., Marowska, J., Gut, G., Wojciechowski, A., et al. (2012). Effect of accelerated electron beam on mechanical properties of human cortical bone: influence of different processing methods. Cell Tissue Bank 13, 375-386. doi: 10.1007/s10561-012-9312-6

Karazisis, D., Ballo, A. M., Petronis, S., Agheli, H., Emanuelsson, L., Thomsen, P., et al. (2016). The role of well-defined nanotopography of titanium implants on osseointegration: cellular and molecular events in vivo. Int. J. Nanomed. 11, 1367-1382. doi: 10.2147/IJN.S101294

Kasraei, S., Sami, L., Hendi, S., AliKhani, M.-Y., Rezaei-Soufi, L., and Khamverdi, Z. (2014). Antibacterial properties of composite resins incorporating silver and zinc oxide nanoparticles on Streptococcus mutans and Lactobacillus. Restor. Dent. Endod. 39, 109-114. doi: 10.5395/rde.2014.39.2.109

Kaur, M., and Singh, K. (2019). Review on titanium and titanium based alloys as biomaterials for orthopaedic applications. Mater. Sci. Eng. C 102, 844-862. doi: 10.1016/j.msec.2019.04.064

Khang, D., Lu, J., Yao, C., Haberstroh, K. M., and Webster, T. J. (2008). The role of nanometer and sub-micron surface features on vascular and bone cell adhesion on titanium. Biomaterials 29, 970-983. doi: 10.1016/j.biomaterials.2007.11.009

Kim, H. M., Kokubo, T., Fujibayashi, S., Nishiguchi, S., and Nakamura, T. (2000). Bioactive macroporous titanium surface layer on titanium substrate. J. Biomed. Mater. Res. 52, 553-557. doi: 10.1002/1097-4636(20001205)52:3<553::AIDJBM14<3.0.CO;2-X

Kim, S.-H., Park, J.-K., Hong, K.-S., Jung, H.-S., and Seo, Y.-K. (2013). Immobilization of BMP-2 on a nano-hydroxyapatite-coated titanium surface using a chitosan calcium chelating agent. Int. J. Artif. Organs 36, 506-517. doi: 10.5301/ijao.5000215

Kumar, S., and Vijayalakshmi, R. (2006). Nanotechnology in dentistry. Indian J. Dent. Res. 6, 62-65. doi: 10.21270/archi.v6i11.2279

Kurella, A., and Dahotre, N. B. (2006). Laser induced hierarchical calcium phosphate structures. Acta Biomater. 2, 677-683. doi: 10.1016/j.actbio.2006.05. 001

Lavenus, S., Berreur, M., Trichet, V., Pilet, P., Louarn, G., and Layrolle, P. (2011). Adhesion and osteogenic differentiation of human mesenchymal stem cells on titanium nanopores. Eur. Cell. Mater. 22, 84-96. doi: 10.22203/eCM.v022a07

Lavenus, S., Rozé, J., Hoornaert, A., Louarn, G., and Layrolle, P. (2012). Impact of nanotechnology on dental implants. Emerg. Nanotechnol. Dent. 1, 71-84. doi: 10.1016/B978-1-4557-7862-1.00005-5

Le Guéhennec, L., Soueidan, A., Layrolle, P., and Inserm, Y. A. (2006). Surface treatments of titanium dental implants for rapid osseointegration. Dent. Mater. 3, 844-854. doi: 10.1016/j.dental.2006.06.025

Lee, J. S., Kim, K., Lee, K., Park, J. P., Yang, K., Cho, S. W., et al. (2015). Surface chemistry of vitamin: pyridoxal 5'-phosphate (vitamin B6) as a multifunctional compound for surface functionalization. Adv. Funct. Mater. 25, 4754-4760. doi: 10.1002/adfm.201501471

Lee, Y. H., Bhattarai, G., Aryal, S., Lee, N. H., Lee, M. H., Kim, T. G., et al. (2010). Modified titanium surface with gelatin nano gold composite increases osteoblast cell biocompatibility. Appl. Surf. Sci. 256, 5882-5887. doi: 10.1016/j. apsusc. 2010.03 .069

Leeuwenburgh, S., Layrolle, P., Barrre, F., De Bruijn, J., Schoonman, J., Van Blitterswijk, C. A., et al. (2001). Osteoclastic resorption of biomimetic calcium phosphate coatings in vitro. J. Biomed. Mater. Res. 56, 208-215. doi: 10.1002/ 1097-4636(200108)56:2<208::AID-JBM1085<3.0.CO;2-R

LeGeros, R. Z. (2002). Properties of osteoconductive biomaterials: calcium phosphates. Clin. Orthop. Relat. Res. 395, 81-98. doi: 10.1097/00003086200202000-00009

li Yang, G., ming He, F., an Hu, J., xiang Wang, X., and fang Zhao, S. (2009). Effects of biomimetically and electrochemically deposited nano-hydroxyapatite coatings on osseointegration of porous titanium implants. Oral Surg. Oral Med. Oral Pathol. Oral Radiol. Endodontol. 107, 782-789. doi: 10.1016/j.tripleo.2008. 12.023

Li, D., Ferguson, S. J., Beutler, T., Cochran, D. L., Sittig, C., Hirt, H. P., et al. (2002). Biomechanical comparison of the sandblasted and acid-etched and the machined and acid-etched titanium surface for dental implants. J. Biomed. Mater. Res. 60, 325-332. doi: 10.1002/jbm.10063

Li, J., Jansen, J. A., Walboomers, X. F., and van den Beucken, J. J. (2020). Mechanical aspects of dental implants and osseointegration: a narrative review. J. Mech. Behav. Biomed. Mater. 103:103574. doi: 10.1016/j.jmbbm.2019.103574

Lim, J. Y., Liu, X., Vogler, E. A., and Donahue, H. J. (2004). Systematic variation in osteoblast adhesion and phenotype with substratum surface characteristics. J. Biomed. Mater. Res. A 68, 504-512. doi: 10.1002/jbm.a.20087 
Linklater, D. P., Baulin, V. A., Juodkazis, S., Crawford, R. J., Stoodley, P., and Ivanova, E. P. (2021). Mechano-bactericidal actions of nanostructured surfaces. Nat. Rev. Microbiol. 19, 8-22. doi: 10.1038/s41579-020-0414-Z

Linkow, L. I. (1966). The radiographic role in endosseous implant interventions. Chronicle 29, 304-311.

Linkow, L. I., and Dorfman, J. D. (1991). Implantology in dentistry. a brief historical perspective. N. Y. State Dent. J. 57, 31-35.

Liu, W., Su, P., Chen, S., Wang, N., Ma, Y., Liu, Y., et al. (2014). Synthesis of TiO2 nanotubes with $\mathrm{ZnO}$ nanoparticles to achieve antibacterial properties and stem cell compatibility. Nanoscale 6, 9050-9062. doi: 10.1039/c4nr01531b

Liu, Y., De Groot, K., and Hunziker, E. B. (2005). BMP-2 liberated from biomimetic implant coatings induces and sustains direct ossification in an ectopic rat model. Bone 36, 745-757. doi: 10.1016/j.bone.2005.02.005

Mante, F. K., Little, K., Mante, M. O., Rawle, C., and Baran, G. R. (2004). Oxidation of titanium. RGD peptide attachment, and matrix mineralization rat bone marrow stromal cells. J. Oral Implantol. 30, 343-349. doi: 10.1563/0.667.1

Marambio-Jones, C., and Hoek, E. M. V. (2010). A review of the antibacterial effects of silver nanomaterials and potential implications for human health and the environment. J. Nanopart. Res. 12, 1531-1551. doi: 10.1007/s11051-0109900-y

Martel-Frachet, V., Ivanova, E. P., Le Clainche, T., Linklater, D., Wong, S., Le, P., et al. (2020). Mechano-bactericidal titanium surfaces for bone tissue engineering. ACS Appl. Mater. Interfaces 12, 48272-48283. doi: 10.1021/acsami. $0 \mathrm{c} 11502$

Martín, J., Vildósola, P., Bersezio, C., Herrera, A., Bortolatto, J., Saad, J. R. C., et al. (2015). Effectiveness of $6 \%$ hydrogen peroxide concentration for tooth bleaching-a double-blind, randomized clinical trial. J. Dent. 43, 965-972. doi: 10.1016/j.jdent.2015.05.011

Memarzadeh, K., Sharili, A. S., Huang, J., Rawlinson, S. C. F., and Allaker, R. P. (2015). Nanoparticulate zinc oxide as a coating material for orthopedic and dental implants. J. Biomed. Mater. Res. A 103, 981-989. doi: 10.1002/jbm.a. 35241

Misch, C. E. (1999). Contemporary implant dentistry. Implant Dent. 8:90. doi: 10.1097/00008505-199901000-00013

Mustafa, K., Wennerberg, A., Wroblewski, J., Hultenby, K., Lopez, B. S., and Arvidson, K. (2001). Determining optimal surface roughness of TiO2 blasted titanium implant material for attachment, proliferation and differentiation of cells derived from human mandibular alveolar bone. Clin. Oral Implants Res. 12, 515-525. doi: 10.1034/j.1600-0501.2001.120513.x

Najeeb, S., Zafar, M. S., Khurshid, Z., and Siddiqui, F. (2016). Applications of polyetheretherketone (PEEK) in oral implantology and prosthodontics. J. Prosthodont. Res. 60, 12-19. doi: 10.1016/j.jpor.2015.10.001

Nazarov, D. V., Zemtsova, E. G., Solokhin, A. Y., Valiev, R. Z., and Smirnov, V. M. (2017). Modification of the surface topography and composition of ultrafine and coarse grained titanium by chemical etching. Nanomaterials 7:15. doi: 10.3390/nano7010015

Nelson, C., André, M., Valiev, R. Z., and Neves, S. (2013). Ultrafine grained titanium for biomedical applications?: an overview of performance. Integr. Med. Res. 2, 340-350. doi: 10.1016/j.jmrt.2013.07.003

Osorio, R., Yamauti, M., Sauro, S., Watson, T. F., and Toledano, M. (2014). Zinc incorporation improves biological activity of beta-tricalcium silicate resinbased cement. J. Endod. 40, 1840-1845. doi: 10.1016/j.joen.2014.06.016

Pachauri, P., Bathala, L. R., and Sangur, R. (2014). Techniques for dental implant nanosurface modifications. J. Adv. Prosthodont. 6, 498-504. doi: 10.4047/jap. 2014.6.6.498

Paital, S. R., and Dahotre, N. B. (2009). Calcium phosphate coatings for bio-implant applications: materials, performance factors, and methodologies. Mater. Sci. Eng. R Rep. 66, 1-70. doi: 10.1016/j.mser.2009.05.001

Palmquist, A., Omar, O. M., Esposito, M., Lausmaa, J., and Thomsen, P. (2010). Titanium oral implants: surface characteristics, interface biology and clinical outcome. J. R. Soc. Interface. 7(Suppl. 5), S515-S527. doi: 10.1098/rsif.2010. 0118.focus

Park, J., Bauer, S., Von Der Mark, K., and Schmuki, P. (2007). Nanosize and vitality: TiO2 nanotube diameter directs cell fate. Nano Lett. 7, 1686-1691. doi: $10.1021 /$ nl070678d

Pattanayak, D. K., Yamaguchi, S., Matsushita, T., Nakamura, T., and Kokubo, T. (2012). Apatite-forming ability of titanium in terms of $\mathrm{pH}$ of the exposed solution. J. R. Soc. Interface 9, 2145-2155. doi: 10.1098/rsif.2012.0107

Perrotti, V., Palmieri, A., Pellati, A., Degidi, M., Ricci, L., Piattelli, A., et al. (2013). Effect of titanium surface topographies on human bone marrow stem cells differentiation in vitro. Odontology 101, 133-139. doi: 10.1007/s10266-0120067-0

Pjetursson, B. E., Brägger, U., Lang, N. P., and Zwahlen, M. (2007). Comparison of survival and complication rates of tooth-supported fixed dental prostheses (FDPs) and implant-supported FDPs and single crowns (SCs). Clin. Oral Implants Res. 18(Suppl. 3), 97-113. doi: 10.1111/j.1600-0501.2007.01439.x

Poon, W., Kingston, B. R., Ouyang, B., Ngo, W., and Chan, W. C. W. (2020). A framework for designing delivery systems. Nat. Nanotechnol. 15, 819-829. doi: 10.1038/s41565-020-0759-5

Poosti, M., Ramazanzadeh, B., Zebarjad, M., Javadzadeh, P., Naderinasab, M., and Shakeri, M. T. (2013). Shear bond strength and antibacterial effects of orthodontic composite containing $\mathrm{TiO} 2$ nanoparticles. Eur. J. Orthod. 35, 676-679. doi: 10.1093/ejo/cjs073

Robertson, S. F., Bandyopadhyay, A., and Bose, S. (2019). Titania nanotube interface to increase adhesion strength of hydroxyapatite sol-gel coatings on Ti-6Al-4V for orthopedic applications. Surf. Coat. Technol. 372, 140-147. doi: 10.1016/j.surfcoat.2019.04.071

Roco, M. C. (2004). Nanoscale science and engineering: unifying and transforming tools. AIChE J. 50, 890-897. doi: 10.1002/aic.10087

Rupp, F., Scheideler, L., Olshanska, N., De Wild, M., Wieland, M., and GeisGerstorfer, J. (2006). Enhancing surface free energy and hydrophilicity through chemical modification of microstructured titanium implant surfaces. J. Biomed. Mater. Res. A 76, 323-334. doi: 10.1002/jbm.a.31045

Salou, L., Hoornaert, A., Louarn, G., and Layrolle, P. (2015). Enhanced osseointegration of titanium implants with nanostructured surfaces: an experimental study in rabbits. Acta Biomater. 11, 494-502. doi: 10.1016/j.actbio. 2014.10.017

Sawase, T., Jimbo, R., Baba, K., Shibata, Y., Ikeda, T., and Atsuta, M. (2008). Photoinduced hydrophilicity enhances initial cell behavior and early bone apposition. Clin. Oral Implants Res. 19, 491-496. doi: 10.1111/j.1600-0501.2007.01509.x

Schroeder, A., van der Zypen, E., Stich, H., and Sutter, F. (1981). The reactions of bone, connective tissue, and epithelium to endosteal implants with titaniumsprayed surfaces. J. Maxillofac. Surg. 9, 15-25. doi: 10.1016/S0301-0503(81) 80007-0

Shibli, J. A., Grassi, S., Piattelli, A., Pecora, G. E., Ferrari, D. S., Onuma, T., et al. (2010). Histomorphometric evaluation of bioceramic molecular impregnated and dual acid-etched implant surfaces in the human posterior maxilla. Clin. Implant Dent. Relat. Res. 12, 281-288. doi: 10.1111/j.1708-8208.2009. 00174.x

Shokuhfar, T., Sinha-Ray, S., Sukotjo, C., and Yarin, A. L. (2013). Intercalation of anti-inflammatory drug molecules within TiO2 nanotubes. RSC Adv. 3, 17380-17386. doi: 10.1039/c3ra42173b

Skallevold, H. E., Rokaya, D., Khurshid, Z., and Zafar, M. S. (2019). Bioactive glass applications in dentistry. Int. J. Mol. Sci. 20, 1-24. doi: 10.3390/ijms20235960

Smeets, R., Stadlinger, B., Schwarz, F., Beck-Broichsitter, B., Jung, O., Precht, C., et al. (2016). Impact of dental implant surface modifications on osseointegration. Biomed. Res. Int. 2016:6285620. doi: 10.1155/2016/6285620

Soto-Peñaloza, D., Zaragozí-Alonso, R., Peñarrocha-Diago, M., and PeñarrochaDiago, M. (2017). The all-on-four treatment concept: systematic review. J. Clin. Exp. Dent. 9, e474-e488. doi: 10.4317/jced.53613

Spriano, S., Yamaguchi, S., Baino, F., and Ferraris, S. (2018). Review article A critical review of multifunctional titanium surfaces?: new Frontiers for improving osseointegration and host response, avoiding bacteria contamination. Acta Biomater. 79, 1-22. doi: 10.1016/j.actbio.2018.08.013

Stevens, M. M., and George, J. H. (2005). Exploring and engineering the cell surface interface. Science 310, 1135-1138. doi: 10.1126/science.1106587

Stojkovic, M., Bojic, S., Volarevic, V., and Ljujic, B. (2014). Dental stem cellscharacteristics and potential. review abstract 1. Histol. Histopathol. 29, 699-706. doi: 10.14670/HH-29.699

Stokholm, R., Isidor, F., and Nyengaard, J. R. (2014). Histologic and histomorphometric evaluation of peri-implant bone of immediate or delayed occlusal-loaded non-splinted implants in the posterior mandible-an experimental study in monkeys. Clin. Oral Implants Res. 25, 1311-1318. doi: $10.1111 / \mathrm{clr} .12274$

Streicher, R. M., Schmidt, M., and Fiorito, S. (2007). Nanosurfaces and nanostructures for artificial orthopedic implants. Nanomedicine 2, 861-874. doi: $10.2217 / 17435889.2 .6 .861$

Sul, Y. T., Johansson, C. B., Röser, K., and Albrektsson, T. (2002). Qualitative and quantitative observations of bone tissue reactions to anodised implants. Biomaterials 23, 1809-1817. doi: 10.1016/S0142-9612(01)00307-6 
Targino, A. G. R., Flores, M. A. P., Santos, V.E. Dos, De Godoy Bené Bezerra, F., De Luna Freire, H., Galembeck, A., et al. (2014). An innovative approach to treating dental decay in children. a new anti-caries agent. J. Mater. Sci. Mater. Med. 25, 2041-2047. doi: 10.1007/s10856-014-5221-5

Toljanic, J., Ekstrand, K., Baer, R., and Thor, A. (2016). Immediate loading of implants in the edentulous maxilla with a fixed provisional restoration without bone augmentation: a report on 5-year outcomes data obtained from a prospective clinical trial. Int. J. Oral Maxillofac. Implants. 31, 1164-1170. doi: 10.11607/jomi.4364

Uludag, H., Norrie, B., Kousinioris, N., and Gao, T. (2001). Engineering temperature-sensitive poly(N-Isopropylacrylamide) polymers as carriers of therapeutic proteins. Biotechnol. Bioeng. 73, 510-521. doi: 10.1002/bit.1086

Van Noort, R. (2012). The future of dental devices is digital. Dent. Mater. 28, 3-12. doi: 10.1016/j.dental.2011.10.014

Vargas-Reus, M. A., Memarzadeh, K., Huang, J., Ren, G. G., and Allaker, R. P. (2012). Antimicrobial activity of nanoparticulate metal oxides against periimplantitis pathogens. Int. J. Antimicrob. Agents 40, 135-139. doi: 10.1016/j. ijantimicag.2012.04.012

Variola, F., Yi, J. H., Richert, L., Wuest, J. D., Rosei, F., and Nanci, A. (2008). Tailoring the surface properties of Ti6Al4V by controlled chemical oxidation. Biomaterials 29, 1285-1298. doi: 10.1016/j.biomaterials.2007.11.040

Von Wilmowsky, C., Bauer, S., Lutz, R., Meisel, M., Neukam, F. W., Toyoshima, T., et al. (2009). In Vivo evaluation of anodic TiO2 Nanotubes: an experimental study in the pig. J. Biomed. Mater. Res. B Appl. Biomater. 89, 165-171. doi: 10.1002/jbm.b.31201

Wang, Q., Wu, L., Liu, S., Cao, P., Yang, J., and Wang, L. (2020a). Nanostructured titanium alloys surface modification technology for antibacterial and osteogenic properties. Curr. Nanosci. 16, 175-193. doi: 10.2174/1573413716666200217104004

Wang, Q., Zhou, P., Liu, S., Attarilar, S., Ma, R. L.-W., Zhong, Y., et al. (2020b). Multi-scale surface treatments of titanium implants for rapid osseointegration: a review. Nanomaterials 10:1244. doi: 10.3390/nano10061244

Wang, X. J., Li, Y. C., Lin, J. G., Yamada, Y., Hodgson, P. D., and Wen, C. E. (2008). In vitro bioactivity evaluation of titanium and niobium metals with different surface morphologies. Acta Biomater 4, 1530-1535. doi: 10.1016/j.actbio.2008. 04.005

Wang, X. X., Hayakawa, S., Tsuru, K., and Osaka, A. (2002). Bioactive titania gel layers formed by chemical treatment of Ti substrate with a $\mathrm{H} 2 \mathrm{O} 2 / \mathrm{HCl}$ solution. Biomaterials 23, 1353-1357. doi: 10.1016/S0142-9612(01)00254-X

Ward, B. C., and Webster, T. J. (2006). The effect of nanotopography on calcium and phosphorus deposition on metallic materials in vitro. Biomaterials 27, 3064-3074. doi: 10.1016/j.biomaterials.2005.12.027

Webster, T. J., Schadler, L. S., Siegel, R. W., and Bizios, R. (2001). Mechanisms of enhanced osteoblast adhesion on nanophase alumina involve vitronectin. Tissue Eng. 7, 291-301. doi: 10.1089/10763270152044152

Webster, T. J., Siegel, R. W., and Bizios, R. (1999). Osteoblast adhesion on nanophase ceramics. Biomaterials 20, 1221-1227. doi: 10.1016/S0142-9612(99) 00020-4

Wennerberg, A. (1998). The importance of surface roughness for implant incorporation. Int. J. Mach. Tools Manuf. 38, 657-662. doi: 10.1016/S08906955(97)00114-4

Werner, S., Huck, O., Frisch, B., Vautier, D., Elkaim, R., Voegel, J.-C., et al. (2009). The effect of microstructured surfaces and laminin-derived peptide coatings on soft tissue interactions with titanium dental implants. Biomaterials 30, 2291-2301. doi: 10.1016/j.biomaterials.2009.01.004

Xie, H., Chua, M., Islam, I., Bentini, R., Cao, T., Viana-Gomes, J. C., et al. (2017). CVD-grown monolayer graphene induces osteogenic but not odontoblastic differentiation of dental pulp stem cells. Dent. Mater. 33, e13-e21. doi: 10.1016/ j.dental.2016.09.030

Xie, Y., Li, J., Yu, Z. M., and Wei, Q. (2017). Nano modified SLA process for titanium implants. Mater. Lett. 186, 38-41. doi: 10.1016/j.matlet.2016.08.079
Yang, F., Chen, C., Zhou, Q., Gong, Y., Li, R., Li, C., et al. (2017). Laser beam melting 3D printing of Ti6Al4V based porous structured dental implants: fabrication, biocompatibility analysis and photoelastic study. Sci. Rep. 7:45360. doi: $10.1038 /$ srep45360

Yang, L., and Miyanaji, H. (2017). "Ceramic additive manufacturing: a review of current status and challenges," in Proceedings of the 28th Annual International Solid Freeform Fabrication Symposium-An Additive Manufacturing Conference, (Austin TX).

Yao, Z. Q., Ivanisenko, Y., Diemant, T., Caron, A., Chuvilin, A., Jiang, J. Z., et al. (2010). Synthesis and properties of hydroxyapatite-containing porous titania coating on ultrafine-grained titanium by micro-arc oxidation. Acta Biomater. 6 , 2816-2825. doi: 10.1016/j.actbio.2009.12.053

Yong, L. T., and Moy, P. K. (2008). Complications of computer-aideddesign/computer-aided-machining-guided (NobelGuide ${ }^{\mathrm{TM}}$ ) surgical implant placement: an evaluation of early clinical results. Clin. Implant Dent. Relat. Res. 10, 123-127. doi: 10.1111/j.1708-8208.2007.00082.x

Yusa, K., Yamamoto, O., Takano, H., Fukuda, M., and Iino, M. (2016). Zincmodified titanium surface enhances osteoblast differentiation of dental pulp stem cells in vitro. Sci. Rep. 6:29462. doi: 10.1038/srep29462

Zafar, M. S., Fareed, M. A., Riaz, S., Latif, M., Habib, S. R., and Khurshid, Z. (2020). Customized therapeutic surface coatings for dental implants. Coatings 10, 1-37. doi: 10.3390/coatings 10060568

Zafar, M. S., Farooq, I., Awais, M., Najeeb, S., Khurshid, Z., and Zohaib, S. (2019). "Chapter 11 - bioactive surface coatings for enhancing osseointegration of dental implants," in Woodhead Publishing Series in Biomaterials, Biomedical, Therapeutic and Clinical Applications of Bioactive Glasses, Woodhead Publishing, ed. G. Kaur 313-329. doi: 10.1016/B978-0-08-102196-5. 00011-2

Zandparsa, R. (2014). Digital imaging and fabrication. Dent. Clin. North Am. 58, 135-158. doi: 10.1016/j.cden.2013.09.012

Zhang, S., and Uludağ, H. (2009). Nanoparticulate systems for growth factor delivery. Pharm. Res. 26, 1561-1580. doi: 10.1007/s11095-0099897-Z

Zhao, G., Zinger, O., Schwartz, Z., Wieland, M., Landolt, D., and Boyan, B. D. (2006). Osteoblast-like cells are sensitive to submicron-scale surface structure. Clin. Oral Implants Res. 17, 258-264. doi: 10.1111/j.1600-0501.2005.01 195.x

Zhao, L., Patel, P. K., and Cohen, M. (2012). Application of virtual surgical planning with computer assisted design and manufacturing technology to cranio-maxillofacial surgery. Arch. Plast. Surg. 39, 309-316. doi: 10.5999/aps. 2012.39.4.309

Zheng, Y., Li, J., Liu, X., and Sun, J. (2012). Antimicrobial and osteogenic effect of Ag-implanted titanium with a nanostructured surface. Int. J. Nanomed. 7, 875-884. doi: 10.2147/IJN.S28450

Zhou, J., Chang, C., Zhang, R., and Zhang, L. (2007). Hydrogels prepared from unsubstituted cellulose in $\mathrm{NaOH} /$ urea aqueous solution. Macromol. Biosci. 7, 804-809. doi: 10.1002/mabi.200700007

Zwemer, J. D. (1986). Dentistry: an illustrated history. J. Prosthet. Dent. 56:126. doi: 10.1016/0022-3913(86)90299-4

Conflict of Interest: The authors declare that the research was conducted in the absence of any commercial or financial relationships that could be construed as a potential conflict of interest.

Copyright (c) 2021 Kandavalli, Wang, Ebrahimi, Gode, Djavanroodi, Attarilar and Liu. This is an open-access article distributed under the terms of the Creative Commons Attribution License (CC BY). The use, distribution or reproduction in other forums is permitted, provided the original author(s) and the copyright owner(s) are credited and that the original publication in this journal is cited, in accordance with accepted academic practice. No use, distribution or reproduction is permitted which does not comply with these terms. 